\title{
Pharmacokinetic Interaction between Sorafenib and Atorvastatin, and Sorafenib and Metformin in Rats
}

\author{
Agnieszka Karbownik ${ }^{1, *}$, Danuta Szkutnik-Fiedler ${ }^{1}$, Andrzej Czyrski ${ }^{2}{ }^{\circledR}$, Natalia Kostewicz ${ }^{1}$, \\ Paulina Kaczmarska ${ }^{1}$, Małgorzata Bekier ${ }^{1}$, Joanna Stanisławiak-Rudowicz ${ }^{3}$, \\ Marta Karaźniewicz-Łada ${ }^{2}$, Anna Wolc ${ }^{4,5}{ }^{\circ}$, Franciszek Główka ${ }^{2}$, Edmund Grześkowiak ${ }^{1}$ and \\ Edyta Szałek ${ }^{1}$ \\ 1 Department of Clinical Pharmacy and Biopharmacy, Poznań University of Medical Sciences, 61-861 Poznań, \\ Poland; dszkutnik@ump.edu.pl (D.S.-F.); kostewicz.natalia@gmail.com (N.K.); \\ p.kaczmarska95@gmail.com (P.K.); gosia.bekier01@gmail.com (M.B.); grzesko@ump.edu.pl (E.G.); \\ eszalek@ump.edu.pl (E.S.) \\ 2 Department of Physical Pharmacy and Pharmacokinetics, Poznań University of Medical Sciences, 60-781 \\ Poznań, Poland; aczyrski@ump.edu.pl (A.C.); mkaraz@ump.edu.pl (M.K.-Ł.); glowka@ump.edu.pl (F.G.) \\ 3 Department of Gynecological Oncology, University Hospital of Lord's Transfiguration, 60-569 Poznań, \\ Poland; stanisl@interia.pl \\ 4 Department of Animal Science, Iowa State University, Ames, IA 50011, USA; awolc@iastate.edu \\ 5 Hy-Line International, Research and Development, Dallas Center, IA 50063, USA \\ * Correspondence: akarbownik@ump.edu.pl; Tel.: +48-61854-60000
}

Received: 10 June 2020; Accepted: 26 June 2020; Published: 28 June 2020

\begin{abstract}
The tyrosine kinase inhibitor sorafenib is the first-line treatment for patients with hepatocellular carcinoma (HCC), in which hyperlipidemia and type 2 diabetes mellitus (T2DM) may often coexist. Protein transporters like organic cation (OCT) and multidrug and toxin extrusion (MATE) are involved in the response to sorafenib, as well as in that to the anti-diabetic drug metformin or atorvastatin, used in hyperlipidemia. Changes in the activity of these transporters may lead to pharmacokinetic interactions, which are of clinical significance. The study aimed to assess the sorafenib-metformin and sorafenib-atorvastatin interactions in rats. The rats were divided into five groups (eight animals in each) that received sorafenib and atorvastatin ( $\left.\mathrm{I}_{\mathrm{SOR}+\mathrm{AT}}\right)$, sorafenib and metformin $\left(\mathrm{II}_{\mathrm{SOR}+\mathrm{MET}}\right)$, sorafenib $\left(\mathrm{III}_{\mathrm{SOR}}\right)$, atorvastatin $\left(\mathrm{IV}_{\mathrm{AT}}\right)$, and metformin $\left(\mathrm{V}_{\mathrm{MET}}\right)$. Atorvastatin significantly increased the maximum plasma concentration $\left(\mathrm{C}_{\max }\right)$ and the area under the plasma concentration-time curve (AUC) of sorafenib by $134.4 \%(p<0.0001)$ and $66.6 \%(p<0.0001)$, respectively. Sorafenib, in turn, caused a significant increase in the AUC of atorvastatin by $94.0 \%(p=0.0038)$ and its metabolites $2-$ hydroxy atorvastatin $(p=0.0239)$ and 4 -hydroxy atorvastatin $(p=0.0002)$ by $55.3 \%$ and $209.4 \%$, respectively. Metformin significantly decreased the AUC of sorafenib $(p=0.0065)$. The AUC ratio (IISOR+MET group/IIISOR group) for sorafenib was equal to 0.6. Sorafenib did not statistically significantly influence the exposure to metformin. The pharmacokinetic interactions observed in this study may be of clinical relevance in HCC patients with coexistent hyperlipidemia or T2DM.
\end{abstract}

Keywords: sorafenib; sorafenib N-oxide; atorvastatin; metformin; pharmacokinetics; drug-drug interaction

\section{Introduction}

Hepatocellular carcinoma (HCC) is one of the most common primary malignant liver tumors whose morbidity is on the rise [1]. Both abnormal lipid metabolism and type 2 diabetes mellitus 
(T2DM) not only notably increase the risk of developing HCC but also accelerate the progress of existing disease and make treatment more challenging [2-4].

Sorafenib is the first-line treatment for patients with HCC. This tyrosine kinase inhibitor (TKI) is transported in the plasma predominantly in a protein-bound form $(99.5 \%)$. It appears in the systemic circulation mostly unchanged (approximately 70-85\%) or as a sorafenib N-oxide (SR_NO; approximately $9-16 \%$ ). Sorafenib penetrates the liver possibly via organic cation transporter-1 (OCT1, gene SLC22A1) and organic anion transporting polypeptide 1B1/3 (OATP1B1/3; SLCO1B1/3) in humans, and in Rattus norvegicus, via Oatp1b2 (Slco1b2) as well. Then, it is metabolized by CYP3A4 to pharmacologically active SR_NO and inactive sorafenib glucuronide (SR_G). SR_G is secreted within the bile into the intestines through multidrug resistance-associated protein 2 (MRP2; ABCC2, $A b c c 2)$, where it can be excreted or converted into a parent compound and re-absorbed into the systemic circulation. Sorafenib is also carried by efflux transporters- $\mathrm{P}-$ glycoprotein $(\mathrm{P}-\mathrm{pg} ; A B C B 1$, $A b c b 1 a)$, breast cancer resistance protein (BCRP; $A B C G 2, A b c g 2)$ and MRP3 (ABCC3, $A b c c 3)$-which also transport SR_G from the hepatocytes to the blood [5-8].

Atorvastatin normalizes the profile of lipids, due to the inhibition of HMG-CoA reductase, which is the rate-limiting step in cholesterol synthesis. It is metabolized by CYP3A4 and a substrate for protein transporters such as OATPs, BCRP, and P-gp [9]. An in vitro study performed on tumor cell lines revealed enhanced cytotoxic effects after the co-use of statins (e.g., atorvastatin) with sorafenib, which probably occurs due to the reduction of sorafenib elimination (shown by the clearance decrease to $0.48 \mathrm{~L} / \mathrm{h}$ ) [10]. A pre-clinical study showed that atorvastatin inhibits Rho-kinase, which is involved in the activation of hepatic stellate cells, which play a significant role in liver fibrosis progression. [11,12]. The addition of statins notably $(p<0.001)$ improved the mean progression-free survival (mPFS) and the mean overall survival (mOS of patients with lung cancer treated with EGFR-TKI (gefitinib or erlotinib) [13], which encourages further research on the impact of statins on oncology treatment.

Metformin is an oral anti-diabetic drug that lowers the blood glucose level mainly by reducing gluconeogenesis and glycogenolysis-most likely by AMP-activated protein kinase (AMPK) stimulation. Metformin is a non-metabolized strong base (a cation at physiological $\mathrm{pH}$ ), which is taken up in the intestine into the bloodstream via plasma membrane monoamine transporter (PMAT; SLC29A4, Slc29a4) and then actively transported into hepatocytes and renal tubular epithelial cells by OCT1, OCT2 (SLC22A2, Slc22a2), and probably OCT3 (SLC22A3). However, its plasma protein-bound fraction is considered negligible. It is secreted in an unchanged form from these cells into the bile or urine, through multidrug and toxin extrusion protein transporter-1 (MATE1; SLC47A1, Slc47a1) and MATE2 (SLC47A2) [14-16]. In the last few years, a growing number of studies have investigated the anti-cancer properties of metformin and TKIs [17-20]. In vitro studies suggest that the addition of metformin may significantly decrease the dose of sorafenib needed to induce the equal inhibition of both the growth and colony and tumor formation of HT74 anaplastic thyroid carcinoma cells [21]. Previous clinical trials suggest that the sorafenib+metformin therapy of patients with advanced HCC may lead to a worse outcome, especially in comparison with, for example, sorafenib+insulin treatment-probably due to the promotion of the development of sorafenib resistance caused by the chronic use of metformin [22-24]. Those findings suggest that there might be also co-existing pharmacokinetic sorafenib-metformin interaction. Additionally, drug-drug interactions (DDIs) of clinical significance involve OCT and MATE transporters. Studies have revealed TKI (i.e., imatinib)-metformin DDIs that affected the efficacy and toxicity of metformin $[15,25]$. Since metformin's pharmacokinetics and, hence, pharmacological effects are dependent on the activity of drug transporters (OCTs, MATEs, and PMAT), drugs that are inhibitors or inducers of these transporters may interfere with the distribution of metformin and ultimately affect both the plasma and intracellular concentrations of this drug. It is known that at high concentrations, especially in patients with widespread metastases, metformin can cause lactic acidosis, a life-threatening adverse reaction [16].

Due to the incidence of HCC in patients treated for hyperlipidemia and/or T2DM, and since the modulation of transporter protein activity may lead to pharmacokinetic interactions resulting 
in increased or decreased absorption of the drug, the aim of the study was to assess the influence of metformin and atorvastatin on the pharmacokinetics of sorafenib (and its active metabolite) and vice versa.

\section{Materials and Methods}

All applicable international, national, and/or institutional guidelines for the care and use of animals were followed. Animals were given a standard diet and water ad libitum, and the experimental protocol for this study was approved by the Local Ethics Committee (Number 02/2019, from 1 March 2019), Poznań University of Life Sciences, Department of Animal Physiology and Biochemistry, Wołyńska 35 Str., 60-637 Poznań, Poland.

\subsection{Animal Experiments}

Adult, healthy, fed male Wistar rats (weight, 475-530 g) were divided into five groups—two study groups and three control groups. The study groups- $\mathrm{I}_{\mathrm{SOR}+\mathrm{AT}}$ and $\mathrm{II}_{\mathrm{SOR}+\mathrm{MET}}$-received sorafenib, along with atorvastatin or metformin, respectively. The control groups- $\mathrm{III}_{\mathrm{SOR}}, \mathrm{IV}_{\mathrm{AT}}$, and $\mathrm{V}_{\mathrm{MET}}$-received sorafenib, atorvastatin, or metformin, respectively, along with $1 \mathrm{~mL}$ of vehicle. The groups of rats did not differ significantly in terms of body mass. Sorafenib $\left(100 \mathrm{mg} / \mathrm{kg}\right.$ body weight (b.w.) [26]; Nexavar ${ }^{\circledR}$, batch number BXHT61, Bayer AG, Leverkusen, Germany), atorvastatin (20 mg/kg b.w. [27]; Tulip ${ }^{\circledR}$, batch number JK9440, Sequoia Capital, Menlo Park, California, USA), and metformin (100 mg/kg b.w. [28]; Metformax ${ }^{\circledR}$, batch number 16518316, Teva Pharmaceutical Industries Ltd., Petach Tikwa, Izrael) were administrated directly into the stomachs of live animals using a gastric probe ( $1 \mathrm{~mL}$ of each solution). A 10\% dimethyl sulfoxide (DMSO) stock for sorafenib tosylate and $0.9 \%$ sodium chloride for atoravastatin and metformin were used to prepare the drug solutions. Blood samples were collected before administration and after dosing at the following time points: $0.5,1,2,3,4,5,6,7,8,10,12,24,30$, 48,72 , and $96 \mathrm{~h}$ (for sorafenib); $0.083,0.25,0.5,0.75,1,2,4,6$, and $12 \mathrm{~h}$ (for atorvastatin); and 0.083 , $0.25,0.5,1,1,5,2,4,6,8,10$, and $24 \mathrm{~h}$ (for metformin). The plasma was separated by centrifugation at $2880 \times \mathrm{g}$ for $10 \mathrm{~min}$ at $4{ }^{\circ} \mathrm{C}$ and stored at $-80{ }^{\circ} \mathrm{C}$ until drug analysis. One subject, assigned to the

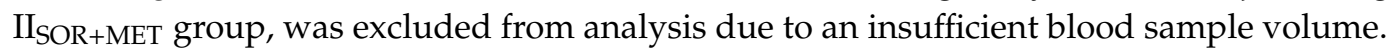

\subsection{Reagents}

All the reagents used for HPLC-UV and the UPLC-MS/MS assays are listed in Table 1.

Table 1. List of all reagents for HPLC-UV and UPLC-MS/MS assays.

\begin{tabular}{cc}
\hline Reagent & CAS Number \\
\hline 1-butanol $^{1}$ & $71-36-3$ \\
2-hydroxy atorvastatin dihydrate monosodium salt $^{2}$ & $214217-86-4$ \\
4-hydroxy atorvastatin disodium salt $^{2}$ & $1276537-18-8$ \\
acetaminophen $^{3}$ & $103-90-2$ \\
acetonitrile $^{3}$ & $75-05-8$ \\
ammonium acetate $^{3}$ & $631-61-8$ \\
ammonium formate $^{3}$ & $540-69-2$ \\
atorvastatin calcium salt trihydrate $^{2}$ & $344423-98-9$ \\
dimethyl sulfoxide $^{3}$ & $67-68-5$ \\
ethyl acetate $^{3}$ & $141-78-6$ \\
formic acid $^{3}$ & $64-18-6$ \\
lapatinib $^{3}$ & $231277-92-9$ \\
metformin hydrochloride $^{3}$ & $1115-70-4$ \\
methanol $^{3}$ & $67-56-1$ \\
n-heptane $^{4}$ & $142-82-5$ \\
\hline
\end{tabular}


Table 1. Cont.

\begin{tabular}{|c|c|}
\hline Reagent & CAS Number \\
\hline sodium hydroxide ${ }^{3}$ & $67-56-1$ \\
\hline sodium hydroxide microprills 5 & 1310-73-2 \\
\hline sorafenib ${ }^{6}$ & 284461-73-0 \\
\hline sorafenib N-oxide ${ }^{6}$ & $583840-03$ \\
\hline rosuvastatin calcium ${ }^{3}$ & $147098-20-2$ \\
\hline $\begin{array}{l}\text { ultrapure water (deionized, distilled, and filtered } \\
\text { through Direct Q3 system) } 4\end{array}$ & $7732-18-5$ \\
\hline
\end{tabular}

\subsection{HPLC-UV Assays}

The concentrations of sorafenib, SR_NO, and metformin were assayed using high-performance liquid chromatography (HPLC) methods with ultraviolet (UV) detection (HPLC Waters 2695 Separations Module with autosampler, Waters 2487 Dual $\lambda$ Absorbance Detector) [29,30].

Separation was achieved by the gradient elution of the mobile phase, from ammonium acetate $(0.1 \mathrm{M}, \mathrm{pH}=3.4$ (adjusted with glacial acetic acid) $)$ as eluent $\mathrm{A}$ to an acetonitrile eluent $\mathrm{B}$, at a flow rate of $1.0 \mathrm{~mL} / \mathrm{min}$ through a reversed-phase C8 column (Symmetry ${ }^{\circledR} \mathrm{C} 8,250 \times 4.6 \mathrm{~mm}, 5.0 \mu \mathrm{m}$ particle size) (Waters Corporation ${ }^{\circledR}$, Milford, Massachusetts, USA). The linear gradient ran from $60 \%$ eluent A and $40 \%$ eluent B to $29 \%$ eluent $A$ and $71 \%$ eluent $B$. The column temperature was maintained at $25^{\circ} \mathrm{C}$, the UV detection wavelength was set at $265 \mathrm{~nm}$, and the injection volume was $20 \mu \mathrm{L}$; lapatinib was used as the internal standard (IS).

The metformin concentrations in rats' plasma were determined according to the method described by Gabr et al. [30]. The conditions were as follows: the UV detection wavelength was $236 \mathrm{~nm}$; a Symmetry ${ }^{\circledR} \mathrm{C} 8,250 \times 4.6 \mathrm{~mm}, 5.0 \mu \mathrm{m}$-particle-size column from Waters was used; the column temperature was maintained at $25^{\circ} \mathrm{C}$; the mobile phase consisted of ammonium formate/acetonitrile $(95: 5, \mathrm{v} / \mathrm{v})$; the $\mathrm{pH}$ of the mobile phase was 6.0 ; the flow rate was $1.0 \mathrm{~mL} / \mathrm{min}$; the volume of each injection was $20 \mu \mathrm{L}$; and the retention times for metformin and the internal standard (acetaminophen) were 3.24 and $9.27 \mathrm{~min}$, respectively.

The calibration curve for sorafenib, SR_NO, and metformin was linear within the range of $0.025-5.0 \mu \mathrm{g} / \mathrm{mL}(\mathrm{r}=0.999), 0.025-0.50 \mu \mathrm{g} / \mathrm{mL}(\mathrm{r}=0.997)$, and $0.1-2.0 \mu \mathrm{g} / \mathrm{mL}(\mathrm{r}=0.996)$, respectively. The lower limit of quantification (LLOQ) was $0.025 \mu \mathrm{g} / \mathrm{mL}$ for sorafenib and SR_NO, and $0.1 \mu \mathrm{g} / \mathrm{mL}$ for metformin. The intra- and inter-day precision (coefficients of variation (CV) and accuracy (\%bias) were as follows: CV $<12 \%$ and \%bias $\leq 7.5 \%$ for sorafenib and SR_NO, and CV $<15 \%$ and $\%$ bias $\leq 15 \%$ for metformin.

\subsection{UPLC-MS/MS Assay}

The concentrations of atorvastatin, 2-hydroxy atorvastatin (2-OH AT), and 4-hydroxy atorvastatin (4-OH AT) were assayed using a UPLC-MS/MS method. The concentration of each of the working solutions was $10 \mu \mathrm{g} / \mathrm{mL}$. The sample preparation involved liquid-liquid extraction. The dry residue was dissolved in $50 \mu \mathrm{L}$ of the mobile phase, and $20 \mu \mathrm{L}$ was injected into the UPLC Nexera system coupled to an LCMS-8030 Triple Quadrupole tandem mass spectrometer (Shimadzu Corp., Kioto, Japan). The analytes were separated in a Zorbax Plus C18 column $(100 \times 2.1 \mathrm{~mm} ; 3.5 \mu \mathrm{m})$ (Agilent Technologies, Santa Clara, California, USA) at a column temperature of $40{ }^{\circ} \mathrm{C}$. The mobile phase was a mixture of de-ionized water (A) and acetonitrile (B), both containing $0.1 \%(\mathrm{v} / \mathrm{v})$ formic acid. The gradient was as follows: $0-2 \mathrm{~min}$, linear from 50 to $70 \% \mathrm{~B} ; 2-4 \mathrm{~min}, 70 \% \mathrm{~B} ; 4-6 \mathrm{~min}$, a return from 70 to $50 \% \mathrm{~B}$; and a post-time of $4 \mathrm{~min}$ with $50 \% \mathrm{~B}$ for column equilibration. The mobile phase flow was set to $0.3 \mathrm{~mL} / \mathrm{min}$. The eluent from the HPLC column was introduced directly to the MS interface, using electrospray ionization in the positive ion mode. The MS parameters were as follows: interface 
temperature, $350{ }^{\circ} \mathrm{C}$; DL temperature, $250{ }^{\circ} \mathrm{C}$; heat block temperature, $400{ }^{\circ} \mathrm{C}$; nebulizing gas flow, $2 \mathrm{~L} / \mathrm{min}$; and drying gas flow, $15 \mathrm{~L} / \mathrm{min}$. The electrospray needle voltage was $3.5 \mathrm{kV}$. The specific transitions for the analytes were monitored using the multiple reaction monitoring (MRM) mode. The most sensitive mass transition was monitored from m/z 558.8 to 440.1 (for atorvastatin), 547.9 to 440.2 (for 2-OH AT and 4-OH AT), and 481.7 to 258.0 (for rosuvastatin).

The UPLC-MS/MS method for atorvastatin, 2-OH AT, and 4-OH AT showed linearity in the concentration range of $0.4-200 \mathrm{ng} / \mathrm{mL}$ in plasma. The intra- and inter-assay precision values, expressed as relative standard deviations, were $<18.7 \%$ for atorvastatin and $4-\mathrm{OH}$ AT, and $<14.0 \%$ for $2-\mathrm{OH}$ AT. The intra- and inter-day accuracy of the method, expressed as the relative error, was $<14.0,<6.1$, and $<10.2 \%$ for atorvastatin, 4-OH AT, and 2-OH AT, respectively.

\subsection{Pharmacokinetic Evaluation}

The Phoenix ${ }^{\circledR}$ WinNonlin version 8.0 software (Certara, Princeton, New Jersey, USA) was used for the calculation of the following pharmacokinetic parameters:

- The elimination rate constant $\left(\mathrm{k}_{\mathrm{e}}\right)$;

- The absorption rate constant $\left(\mathrm{k}_{\mathrm{a}}\right)$;

- The elimination half-life $\left(\mathrm{t}_{1 / 2}\right)$;

- The maximum plasma concentration $\left(\mathrm{C}_{\max }\right)$;

- The time to reach the $\mathrm{C}_{\max }\left(\mathrm{t}_{\max }\right)$;

- The total area under the concentration-time curve ( $\mathrm{AUC}_{0-\mathrm{t}}$ and $\left.\mathrm{AUC}_{0-\infty}\right)$;

- The apparent plasma drug clearance $(\mathrm{Cl} / \mathrm{F})$;

- $\quad$ The apparent volume of distribution $\left(\mathrm{V}_{\mathrm{d}} / \mathrm{F}\right)$.

The above-mentioned parameters underwent statistical analysis.

\subsection{Statistical Analysis}

The statistical analyses were performed using the Statistica software (Statistica, Tulsa, OK, USA) version 13.3 (for atorvastatin, 2-OH AT, 4-OH AT, and metformin) and SAS software (SAS Institute Inc., Cary, NC 27513, USA) version 9.4 (for sorafenib and SR_NO). Normality was estimated with the Shapiro-Wilk test. For sorafenib and SR_NO, analysis of variance (PROC GLM) was used to test the significance of the differences between the groups for variables without significant deviations from normality. Welch's test was used when the assumption of homogeneity of variance was not met, and ANOVA was followed by post-hoc Tukey tests. For metformin, atorvastatin, and its metabolites, the differences between the normally distributed variables were determined with the Student's t-test. For all the remaining variables, the Mann-Whitney $U$ test was applied, and a $p$-value $<0.05$ was considered significant.

\section{Results}

All the data are expressed as the mean values \pm standard deviations (SD).

\subsection{The Influence of Atorvastatin on the Pharmacokinetics of Sorafenib and SR_NO}

After the administration of sorafenib with atorvastatin ( $\mathrm{I}_{\mathrm{SOR}+\mathrm{AT}}$ group), the $\mathrm{C}_{\max }, \mathrm{AUC}_{0-\mathrm{t}}$, and $\mathrm{AUC}_{0-\infty}$ of sorafenib increased by $134.6,66.6$, and $58.7 \%$, respectively, compared with those in the

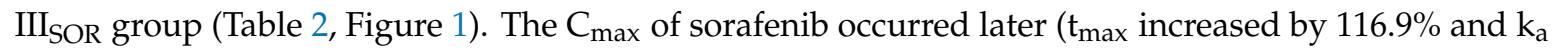
decreased by $73.0 \%$ ) in the ISOR+AT group. The value of the $t_{1 / 2}$ of sorafenib decreased in the presence of atorvastatin (the $t_{1 / 2}$ was lower by 0.3 -fold). However, there were no statistically significant differences for the $\mathrm{k}_{\mathrm{el}}$ and $\mathrm{Cl} / \mathrm{F}$ of sorafenib. $\mathrm{V}_{\mathrm{d}} / \mathrm{F}$ was also comparable between the $\mathrm{III}_{\mathrm{SOR}}$ and $\mathrm{I}_{\mathrm{SOR}+\mathrm{AT}}$ groups. 
Table 2. Plasma pharmacokinetic parameters of sorafenib and its metabolite N-oxide after the oral administration of a single dose of sorafenib $(100 \mathrm{mg} / \mathrm{kg} \mathrm{b.w.)}$ to the III $\mathrm{SOR}$ group, sorafenib+atorvastatin $(100 \mathrm{mg} / \mathrm{kg} \mathrm{b.w.}+20 \mathrm{mg} / \mathrm{kg} \mathrm{b.w}$.) to the ISOR+AT group, and sorafenib+metformin $\left(100 \mathrm{mg} / \mathrm{kg}\right.$ b.w. $+100 \mathrm{mg} / \mathrm{kg}$ b.w.) to the $\mathrm{II}_{\mathrm{SOR}+\mathrm{MET}}$ group.

\begin{tabular}{|c|c|c|c|c|c|}
\hline $\begin{array}{l}\text { Pharmacokinetic } \\
\text { Parameters }{ }^{1}\end{array}$ & $\begin{array}{l}\text { IIISOR } \\
(n=8)\end{array}$ & $\begin{array}{c}\text { ISOR+AT } \\
(n=8)\end{array}$ & $\begin{array}{l}\text { IISOR+MET } \\
\quad(n=7)\end{array}$ & $\begin{array}{c}p \text {-Value } \\
\text { ISOR+AT }_{\text {SOR }} \\
\text { vs. III }\end{array}$ & $\begin{array}{c}p \text {-Value } \\
\text { II }_{\text {SOR+MET }} \\
\text { vs. III } \\
\text { SOR }\end{array}$ \\
\hline \multicolumn{6}{|c|}{ Sorafenib } \\
\hline $\mathrm{C}_{\max }(\mu \mathrm{g} / \mathrm{mL})$ & $\begin{array}{c}1.56 \pm 0.35 \\
(22.6)\end{array}$ & $\begin{array}{c}3.66 \pm 1.21 \\
(33.1)\end{array}$ & $\begin{array}{c}1.27 \pm 0.38 \\
(30.2)\end{array}$ & $<0.0001$ & 0.7499 \\
\hline $\mathrm{AUC}_{0-\mathrm{t}}(\mu \mathrm{g} \times \mathrm{h} / \mathrm{mL})$ & $\begin{array}{c}62.83 \pm 16.14 \\
(25.7)\end{array}$ & $\begin{array}{c}104.67 \pm 18.90 \\
(18.1)\end{array}$ & $\begin{array}{c}35.16 \pm 8.36 \\
(23.8)\end{array}$ & $<0.0001$ & 0.0065 \\
\hline $\operatorname{AUC}_{0-\infty}(\mu \mathrm{g} \times \mathrm{h} / \mathrm{mL})$ & $\begin{array}{c}67.05 \pm 16.70 \\
(24.9)\end{array}$ & $\begin{array}{c}106.41 \pm 19.33 \\
\quad(18.2)\end{array}$ & $\begin{array}{c}36.79 \pm 8.96 \\
(24.4)\end{array}$ & 0.0002 & 0.0041 \\
\hline $\mathrm{t}_{\max }(\mathrm{h})$ & $\begin{array}{c}5.13 \pm 2.17 \\
(42.3)\end{array}$ & $\begin{array}{c}11.13 \pm 5.54 \\
(49.8)\end{array}$ & $\begin{array}{c}7.43 \pm 2.29 \\
(30.9)\end{array}$ & 0.0117 & 0.4722 \\
\hline $\mathrm{k}_{\mathrm{a}}\left(\mathrm{h}^{-1}\right)$ & $\begin{array}{c}0.74 \pm 0.31 \\
\quad(42.5)\end{array}$ & $\begin{array}{c}0.20 \pm 0.11 \\
(53.2)\end{array}$ & $\begin{array}{c}0.35 \pm 0.23 \\
\quad(66.8)\end{array}$ & 0.0005 & 0.0106 \\
\hline $\mathrm{k}_{\mathrm{el}}\left(\mathrm{h}^{-1}\right)$ & $\begin{array}{c}0.035 \pm 0.01 \\
(30.3)\end{array}$ & $\begin{array}{c}0.05 \pm 0.02 \\
(30.6)\end{array}$ & $\begin{array}{c}0.05 \pm 0.01 \\
(24.4)\end{array}$ & 0.0637 & 0.3306 \\
\hline $\mathrm{t}_{1 / 2}(\mathrm{~h})$ & $\begin{array}{c}21.89 \pm 7.79 \\
(35.6)\end{array}$ & $\begin{array}{c}14.70 \pm 3.17 \\
(21.5)\end{array}$ & $\begin{array}{c}16.33 \pm 3.72 \\
(22.8)\end{array}$ & 0.0372 & 0.1386 \\
\hline $\mathrm{Cl} / \mathrm{F}(\mathrm{L} / \mathrm{h} \times \mathrm{kg})$ & $\begin{array}{c}0.80 \pm 0.22 \\
(27.1)\end{array}$ & $\begin{array}{c}0.48 \pm 0.09 \\
(18.3)\end{array}$ & $\begin{array}{c}1.41 \pm 0.50 \\
(35.3)\end{array}$ & 0.1118 & 0.0026 \\
\hline $\mathrm{V}_{\mathrm{d}} / \mathrm{F}(\mathrm{L})$ & $\begin{array}{c}25.30 \pm 11.59 \\
(45.8)\end{array}$ & $\begin{array}{c}9.98 \pm 2.48 \\
(24.9)\end{array}$ & $\begin{array}{c}34.15 \pm 18.74 \\
(54.9)\end{array}$ & 0.0570 & 0.3716 \\
\hline \multicolumn{6}{|c|}{ Sorafenib N-oxide } \\
\hline $\mathrm{C}_{\max }(\mu \mathrm{g} / \mathrm{mL})$ & $\begin{array}{c}0.11 \pm 0.02 \\
\quad(21.8)\end{array}$ & $\begin{array}{c}0.38 \pm 0.09 \\
(24.0)\end{array}$ & $\begin{array}{l}0.13 \pm 0.04 \\
\quad(31.5)\end{array}$ & $<0.0001$ & 0.8981 \\
\hline $\mathrm{AUC}_{0-\mathrm{t}}(\mu \mathrm{g} \times \mathrm{h} / \mathrm{mL})$ & $\begin{array}{c}4.10 \pm 1.56 \\
\quad(38.1)\end{array}$ & $\begin{array}{c}14.04 \pm 2.11 \\
(15.1)\end{array}$ & $\begin{array}{c}5.49 \pm 2.39 \\
\quad(43.6)\end{array}$ & $<0.0001$ & 0.4029 \\
\hline $\operatorname{AUC}_{0-\infty}(\mu \mathrm{g} \times \mathrm{h} / \mathrm{mL})$ & $\begin{array}{c}8.61 \pm 2.19 \\
(25.4)\end{array}$ & $\begin{array}{c}16.32 \pm 2.50 \\
(15.3)\end{array}$ & $\begin{array}{c}8.55 \pm 2.36 \\
(27.5)\end{array}$ & $<0.0001$ & 0.9988 \\
\hline $\mathrm{t}_{\max }(\mathrm{h})$ & $\begin{array}{c}16.38 \pm 8.21 \\
(50.1)\end{array}$ & $\begin{array}{c}19.50 \pm 8.12 \\
(41.7)\end{array}$ & $\begin{array}{c}21.43 \pm 6.80 \\
\quad(31.7)\end{array}$ & 0.7055 & 0.4363 \\
\hline $\mathrm{k}_{\mathrm{el}}\left(\mathrm{h}^{-1}\right)$ & $\begin{array}{c}0.016 \pm 0.010 \\
(60.9)\end{array}$ & $\begin{array}{c}0.028 \pm 0.009 \\
(31.4)\end{array}$ & $\begin{array}{c}0.018 \pm 0.009 \\
(51.9)\end{array}$ & 0.0638 & 0.9473 \\
\hline$t_{1 / 2}(h)$ & $\begin{array}{c}53.31 \pm 25.23 \\
\quad(47.3)\end{array}$ & $\begin{array}{c}27.04 \pm 8.49 \\
(31.4)\end{array}$ & $\begin{array}{c}45.98 \pm 20.71 \\
\quad(45.0)\end{array}$ & 0.0347 & 0.7487 \\
\hline \multicolumn{6}{|c|}{ Sorafenib N-oxide/Sorafenib } \\
\hline $\mathrm{C}_{\max }(\mu \mathrm{g} / \mathrm{mL})$ & $\begin{array}{c}0.07 \pm 0.02 \\
\quad(26.8)\end{array}$ & $\begin{array}{l}0.11 \pm 0.03 \\
\quad(26.9)\end{array}$ & $\begin{array}{l}0.10 \pm 0.03 \\
\quad(26.0)\end{array}$ & 0.0410 & 0.1231 \\
\hline $\mathrm{AUC}_{0-\mathrm{t}}(\mu \mathrm{g} \times \mathrm{h} / \mathrm{mL})$ & $\begin{array}{c}0.07 \pm 0.02 \\
\quad(37.1)\end{array}$ & $\begin{array}{l}0.14 \pm 0.02 \\
\quad(12.7)\end{array}$ & $\begin{array}{l}0.16 \pm 0.06 \\
\quad(35.6)\end{array}$ & 0.0026 & 0.0002 \\
\hline $\mathrm{AUC}_{0-\infty}(\mu \mathrm{g} \times \mathrm{h} / \mathrm{mL})$ & $\begin{array}{l}0.14 \pm 0.05 \\
\quad(38.1)\end{array}$ & $\begin{array}{l}0.16 \pm 0.03 \\
\quad(16.7)\end{array}$ & $\begin{array}{l}0.25 \pm 0.11 \\
\quad(42.2)\end{array}$ & 0.8226 & 0.0108 \\
\hline
\end{tabular}

$\mathrm{C}_{\text {max }}$, maximum observed plasma concentration; $\mathrm{AUC}_{0-\mathrm{t}}$, area under the plasma concentration-time curve from zero to the time of last measurable concentration; $\mathrm{AUC}_{0-\infty}$, area under the plasma concentration-time curve from zero to infinity; $\mathrm{t}_{\max }$, time to the first occurrence of $\mathrm{C}_{\max } ; \mathrm{k}_{\mathrm{a}}$, absorption rate constant; $\mathrm{k}_{\mathrm{el}}$, elimination rate constant; $t_{1 / 2}$, half-life in the elimination phase; $C l / F$, apparent plasma drug clearance; $V_{d} / F$, apparent volume of distribution; b.w., body weight. Arithmetic means \pm standard deviations (SD) are shown with coefficients of variation $(\mathrm{CV})(\%)$ in brackets. 


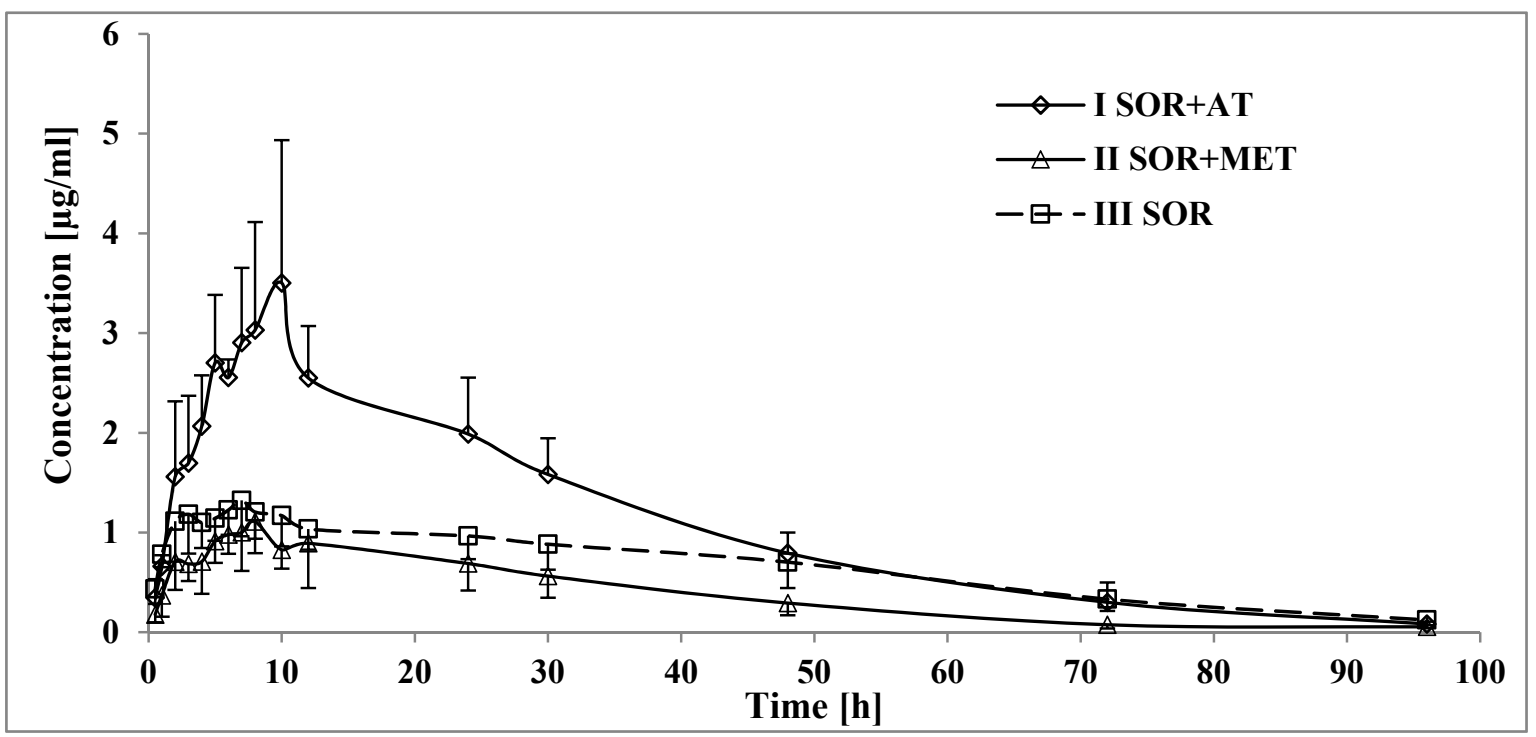

Figure 1. The sorafenib plasma concentration-time profiles in rats receiving sorafenib (III $\mathrm{SOR}_{\text {), }}$ sorafenib+metformin (IISOR+MET), and sorafenib+atorvastatin $\left(\mathrm{I}_{\mathrm{SOR}+\mathrm{AT}}\right)$.

Atorvastatin increased the SR_NO $C_{\max }, \mathrm{AUC}_{0-\mathrm{t}}$, and $\mathrm{AUC}_{0-\infty}$ by 245.5, 242.4, and 89.5\%, respectively (Table 2, Figure 2); the $\mathrm{t}_{0.5}$ of SR_NO in the ISOR+AT group decreased by 0.4 -fold. However, no statistically significant differences were revealed for $k_{\mathrm{el}}$ and $t_{\max }$.

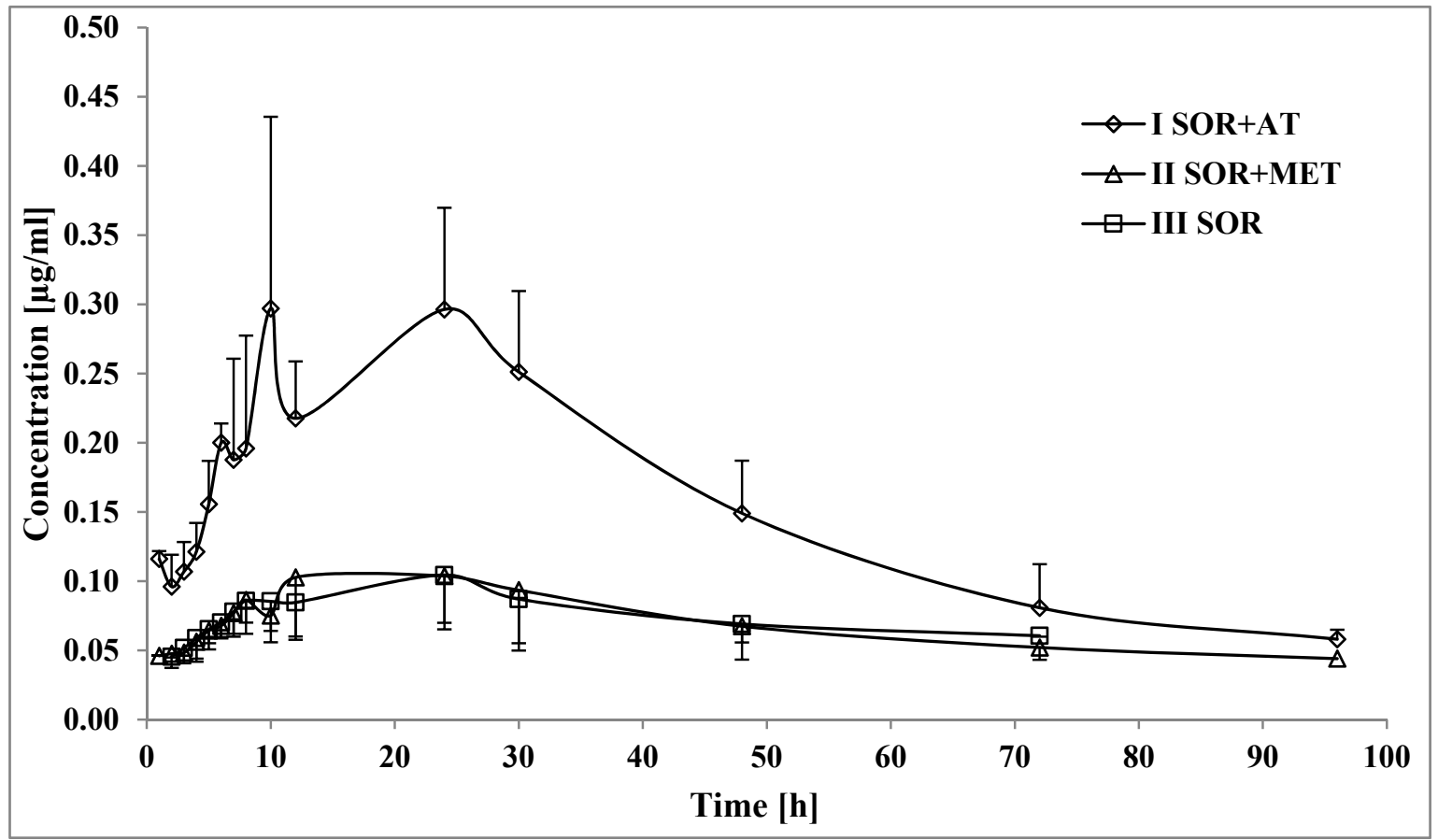

Figure 2. The sorafenib N-oxide plasma concentration-time profiles in rats receiving sorafenib (IIISOR), sorafenib+metformin $\left(\mathrm{II}_{\mathrm{SOR}+\mathrm{MET}}\right)$, and sorafenib+atorvastatin $\left(\mathrm{I}_{\mathrm{SOR}+\mathrm{AT}}\right)$.

\subsection{The Influence of Sorafenib on the Pharmacokinetics of Atorvastatin, 2-OH AT, and 4-OH AT}

When atorvastatin and sorafenib were co-administered, the $\mathrm{AUC}_{0-\mathrm{t}}$ and $\mathrm{AUC}_{0-\infty}$ of atorvastatin increased by 94.0 and $93.2 \%$, respectively (Table 3, Figure 3). In the group of rats receiving both drugs, atorvastatin $\mathrm{t}_{\max }$ was longer than that in the $\mathrm{IV}_{\mathrm{AT}}$ group. No statistically significant differences were revealed for $C_{\max }, k_{a}, k_{e l}$, and $t_{1 / 2}$. 
Table 3. Plasma pharmacokinetic parameters for atorvastatin, 2-OH AT, and 4-OH AT after he oral administration of a single dose of atorvastatin $\left(20 \mathrm{mg} / \mathrm{kg}\right.$ b.w.) to the $\mathrm{IV}_{\mathrm{AT}}$ group and sorafenib+atorvastatin (100 mg/kg b.w. $+20 \mathrm{mg} / \mathrm{kg}$ b.w.) to the ISOR+AT group.

\begin{tabular}{|c|c|c|c|}
\hline $\begin{array}{c}\text { Pharmacokinetic } \\
\text { Parameters }^{1}\end{array}$ & $\begin{array}{c}\mathrm{IV}_{\mathrm{AT}} \\
(n=8)\end{array}$ & $\begin{array}{c}\mathrm{I}_{\mathrm{SOR}+\mathrm{AT}} \\
(n=8)\end{array}$ & $\begin{array}{c}p \text {-Value } \\
\text { I }_{\mathrm{SOR}+\mathrm{AT}} \text { vs. } \mathrm{IV}_{\mathrm{AT}}\end{array}$ \\
\hline \multicolumn{4}{|c|}{ Atorvastatin } \\
\hline $\mathrm{C}_{\max }(\mathrm{ng} / \mathrm{mL})$ & $\begin{array}{c}72.76 \pm 27.21 \\
(37.4)\end{array}$ & $\begin{array}{c}81.77 \pm 38.24 \\
\quad(46.8)\end{array}$ & $0.5957^{1}$ \\
\hline $\mathrm{AUC}_{0-\mathrm{t}}(\mathrm{ng} \times \mathrm{h} / \mathrm{mL})$ & $\begin{array}{c}186.70 \pm 74.03 \\
\quad(39.7)\end{array}$ & $\begin{array}{c}362.21 \pm 90.82 \\
(25.1)\end{array}$ & $0.0038^{2}$ \\
\hline $\mathrm{AUC}_{0-\infty}(\mathrm{ng} \times \mathrm{h} / \mathrm{mL})$ & $\begin{array}{c}194.01 \pm 72.41 \\
\quad(37.3)\end{array}$ & $\begin{array}{c}374.12 \pm 87.23 \\
\quad(23.3)\end{array}$ & $0.0038^{2}$ \\
\hline$t_{\max }(h)$ & $\begin{array}{c}1.26 \pm 0.69 \\
(54.5)\end{array}$ & $\begin{array}{c}2.75 \pm 1.75 \\
(63.7)\end{array}$ & $0.0419^{1}$ \\
\hline $\mathrm{k}_{\mathrm{a}}\left(\mathrm{h}^{-1}\right)$ & $\begin{array}{l}1.95 \pm 3.03 \\
(155.4)\end{array}$ & $\begin{array}{l}0.79 \pm 0.62 \\
\quad(78.7)\end{array}$ & $0.1893^{2}$ \\
\hline $\mathrm{k}_{\mathrm{el}}\left(\mathrm{h}^{-1}\right)$ & $\begin{array}{l}0.24 \pm 0.08 \\
\quad(33.7)\end{array}$ & $\begin{array}{l}0.34 \pm 0.11 \\
\quad(31.6)\end{array}$ & $0.0704^{1}$ \\
\hline $\mathrm{t}_{1 / 2}(\mathrm{~h})$ & $\begin{array}{c}3.22 \pm 1.33 \\
(41.4)\end{array}$ & $\begin{array}{l}2.27 \pm 0.80 \\
(35.1)\end{array}$ & $0.1071^{1}$ \\
\hline $\mathrm{Cl} / \mathrm{F}(\mathrm{L} / \mathrm{h} \times \mathrm{kg})$ & $\begin{array}{c}54.31 \pm 13.87 \\
\quad(25.5)\end{array}$ & $\begin{array}{l}27.71 \pm 7.46 \\
\quad(29.9)\end{array}$ & $0.0003^{1}$ \\
\hline $\mathrm{V}_{\mathrm{d}} / \mathrm{F}(\mathrm{L})$ & $\begin{array}{c}257.67 \pm 132.63 \\
(51.5)\end{array}$ & $\begin{array}{l}93.91 \pm 50.93 \\
\quad(54.2)\end{array}$ & $0.0028^{2}$ \\
\hline \multicolumn{4}{|c|}{ 2-OH AT } \\
\hline $\mathrm{C}_{\max }(\mathrm{ng} / \mathrm{mL})$ & $\begin{array}{c}175.20 \pm 116.62 \\
(66.6)\end{array}$ & $\begin{array}{c}185.82 \pm 90.16 \\
(48.5)\end{array}$ & $0.4948^{2}$ \\
\hline $\mathrm{AUC}_{0-\mathrm{t}}(\mathrm{ng} \times \mathrm{h} / \mathrm{mL})$ & $\begin{array}{c}617.32 \pm 277.54 \\
\quad(45.0)\end{array}$ & $\begin{array}{c}958.91 \pm 342.91 \\
\quad(35.8)\end{array}$ & $0.0239^{2}$ \\
\hline $\mathrm{AUC}_{0-\infty}(\mathrm{ng} \times \mathrm{h} / \mathrm{mL})$ & $\begin{array}{c}695.68 \pm 297.16 \\
(42.7)\end{array}$ & $\begin{array}{c}993.97 \pm 343.87 \\
(34.6)\end{array}$ & $0.0846^{1}$ \\
\hline \multicolumn{4}{|c|}{ 2-OH AT/atorvastatin } \\
\hline $\mathrm{C}_{\max }(\mathrm{ng} / \mathrm{mL})$ & $\begin{array}{l}2.35 \pm 1.12 \\
\quad(47.6)\end{array}$ & $\begin{array}{l}2.43 \pm 1.06 \\
\quad(43.6)\end{array}$ & $1.0000^{2}$ \\
\hline $\mathrm{AUC}_{0-\mathrm{t}}(\mathrm{ng} \times \mathrm{h} / \mathrm{mL})$ & $\begin{array}{l}3.30 \pm 0.70 \\
\quad(21.3)\end{array}$ & $\begin{array}{l}2.66 \pm 0.74 \\
\quad(27.8)\end{array}$ & $0.0520^{2}$ \\
\hline $\mathrm{AUC}_{0-\infty}(\mathrm{ng} \times \mathrm{h} / \mathrm{mL})$ & $\begin{array}{l}3.61 \pm 1.12 \\
\quad(31.0)\end{array}$ & $\begin{array}{l}2.67 \pm 0.76 \\
\quad(28.3)\end{array}$ & $0.0312^{2}$ \\
\hline \multicolumn{4}{|c|}{ 4-OH AT } \\
\hline $\mathrm{C}_{\max }(\mathrm{ng} / \mathrm{mL})$ & $\begin{array}{c}3.18 \pm 1.78 \\
(55.9)\end{array}$ & $\begin{array}{c}7.22 \pm 2.42 \\
(33.5)\end{array}$ & $0.0019^{1}$ \\
\hline $\mathrm{AUC}_{0-\mathrm{t}}(\mathrm{ng} \times \mathrm{h} / \mathrm{mL})$ & $\begin{array}{l}14.63 \pm 5.57 \\
\quad(38.1)\end{array}$ & $\begin{array}{c}45.26 \pm 16.72 \\
\quad(34.9)\end{array}$ & $0.0002^{1}$ \\
\hline $\mathrm{AUC}_{0-\infty}(\mathrm{ng} \times \mathrm{h} / \mathrm{mL})$ & $\begin{array}{l}19.22 \pm 7.06 \\
\quad(36.7)\end{array}$ & $\begin{array}{c}61.59 \pm 21.50 \\
\quad(34.9)\end{array}$ & $0.0001^{1}$ \\
\hline \multicolumn{4}{|c|}{ 4-OH AT/atorvastatin } \\
\hline $\mathrm{C}_{\max }(\mathrm{ng} / \mathrm{mL})$ & $\begin{array}{l}0.04 \pm 0.02 \\
\quad(40.7)\end{array}$ & $\begin{array}{c}0.10 \pm 0.05 \\
(50.3)\end{array}$ & $0.0084^{1}$ \\
\hline $\mathrm{AUC}_{0-\mathrm{t}}(\mathrm{ng} \times \mathrm{h} / \mathrm{mL})$ & $\begin{array}{l}0.08 \pm 0.02 \\
\quad(28.3)\end{array}$ & $\begin{array}{l}0.13 \pm 0.06 \\
\quad(44.0)\end{array}$ & $0.0239^{2}$ \\
\hline $\mathrm{AUC}_{0-\infty}(\mathrm{ng} \times \mathrm{h} / \mathrm{mL})$ & $\begin{array}{l}0.10 \pm 0.04 \\
\quad(38.1)\end{array}$ & $\begin{array}{l}0.17 \pm 0.08 \\
\quad(47.2)\end{array}$ & $0.0239^{2}$ \\
\hline
\end{tabular}

$\mathrm{C}_{\text {max }}$, maximum observed plasma concentration; $\mathrm{AUC}_{0-\mathrm{t}}$, area under the plasma concentration-time curve from zero to the time of last measurable concentration; $\mathrm{AUC}_{0-\infty}$, area under the plasma concentration-time curve from zero to infinity; $\mathrm{t}_{\max }$, time to the first occurrence of $\mathrm{C}_{\mathrm{max}} ; \mathrm{k}_{\mathrm{a}}$, absorption rate constant; $\mathrm{k}_{\mathrm{el}}$, elimination rate constant; $t_{1 / 2}$, half-life in the elimination phase; $C l / F$, apparent plasma drug clearance; $V_{d} / F$, apparent volume of distribution; b.w., body weight. Arithmetic means \pm standard deviations (SD) are shown with coefficients of variation (CV) (\%) in brackets; ${ }^{1}$ t-test; ${ }^{2}$ Mann-Whitney U test. 


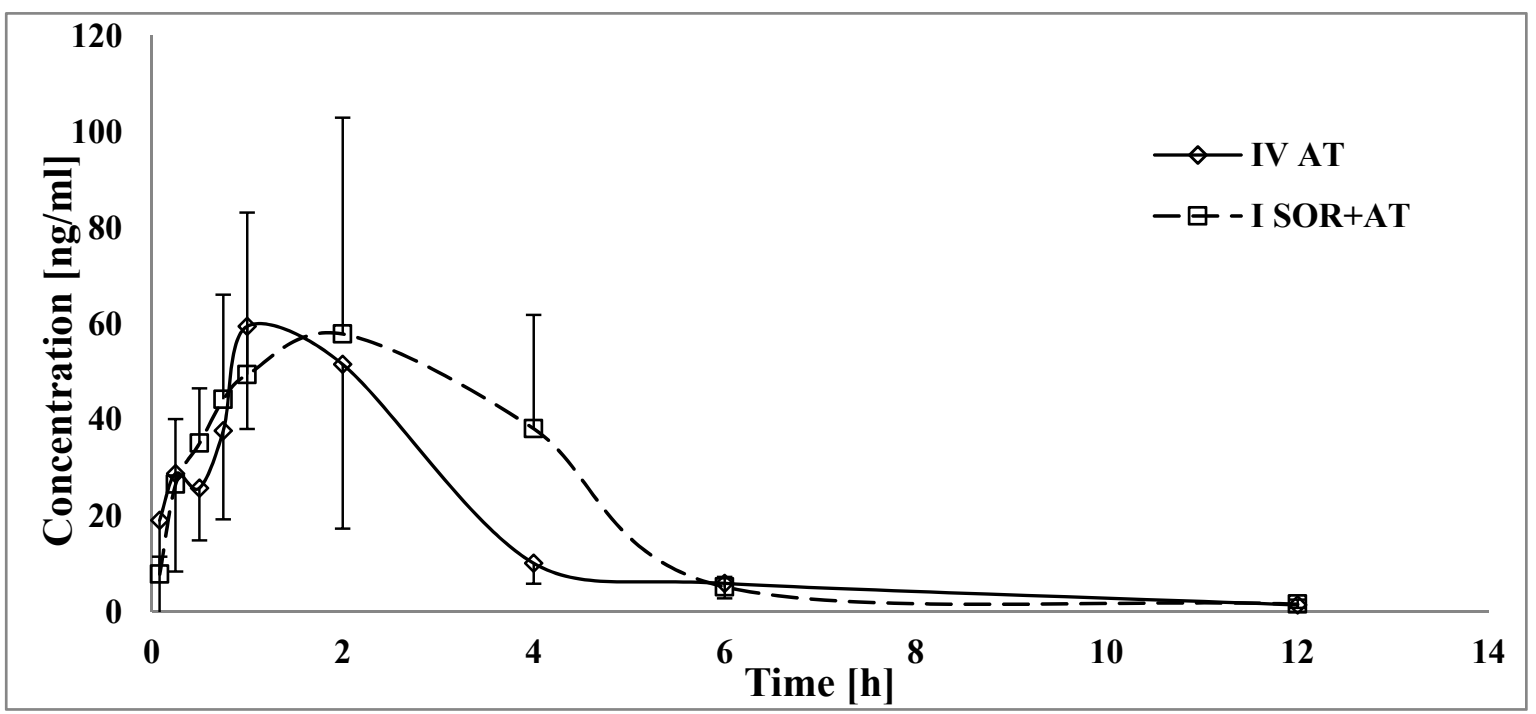

Figure 3. The atorvastatin plasma concentration-time profiles in rats receiving sorafenib $\left(\mathrm{IV}_{\mathrm{AT}}\right)$ and sorafenib+atorvastatin ( $\left.\mathrm{I}_{\mathrm{SOR}+\mathrm{AT}}\right)$.

The $\mathrm{C}_{\max }$ of 2-OH AT was similar in both the atorvastatin and atorvastatin+sorafenib groups (Table 3, Figure 4). The exposure to 2-OH AT was significantly higher in the presence of sorafenib, which was reflected by increased values of $\mathrm{AUC}_{0-\mathrm{t}}$ and $\mathrm{AUC}_{0-\infty}$, but for $\mathrm{AUC}_{0-\infty}$, there was no statistical significance. The ratios of $\mathrm{AUC}_{0-\mathrm{t}}$ and $\mathrm{AUC}_{0-\infty}$ ( $\mathrm{I}_{\mathrm{SOR}+\mathrm{AT}}$ group/IV $\mathrm{AT}$ group) for atorvastatin were increased by 0.5 - and 0.4 -fold, respectively. In the $\mathrm{I}_{\mathrm{SOR}+\mathrm{AT}}$ group, the $\mathrm{t}_{\max }$ of 2-OH AT was longer than that in the $\mathrm{IV}_{\mathrm{AT}}$ group, but there was no statistical significance. No statistically significant differences were revealed for $\mathrm{k}_{\mathrm{el}}$ and $\mathrm{t}_{1 / 2}$. Sorafenib elevated the $4-\mathrm{OH}$ AT $\mathrm{C}_{\max }$ by $127.0 \%$ (Table 3, Figure 5). When atorvastatin and sorafenib were co-administered, the $\mathrm{AUC}_{0-\mathrm{t}}$ and $\mathrm{AUC}_{0-\infty}$ of 4-OH AT increased by 320.9 and $220.5 \%$, respectively. There were no significant differences among the groups for the following pharmacokinetic parameters of $4-\mathrm{OH} \mathrm{AT:} \mathrm{k}_{\mathrm{el}}, \mathrm{t}_{1 / 2}$, and $\mathrm{t}_{\mathrm{max}}$.

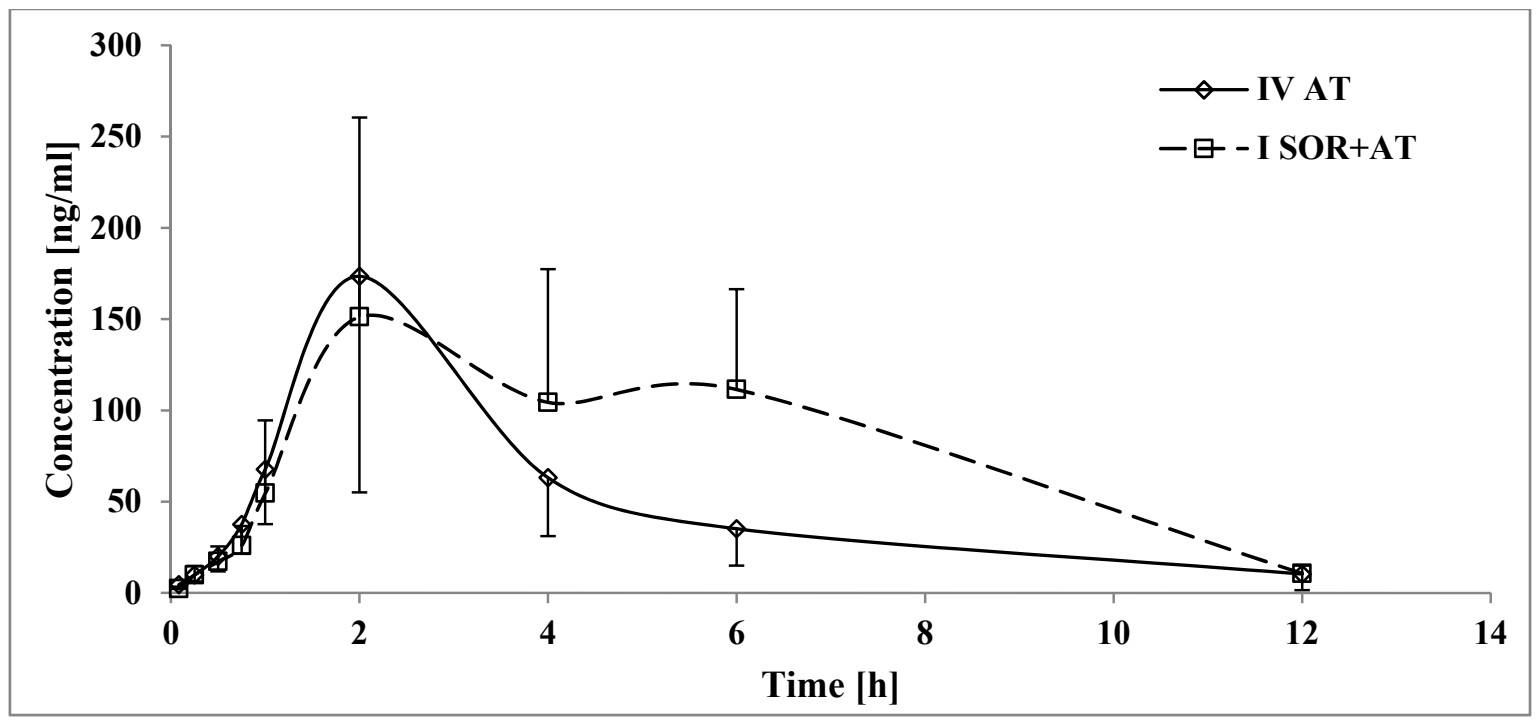

Figure 4. The 2-OH AT plasma concentration-time profiles in rats receiving sorafenib $\left(\mathrm{IV}_{\mathrm{AT}}\right)$ and sorafenib+atorvastatin $\left(\mathrm{I}_{\mathrm{SOR}+\mathrm{AT}}\right)$. 


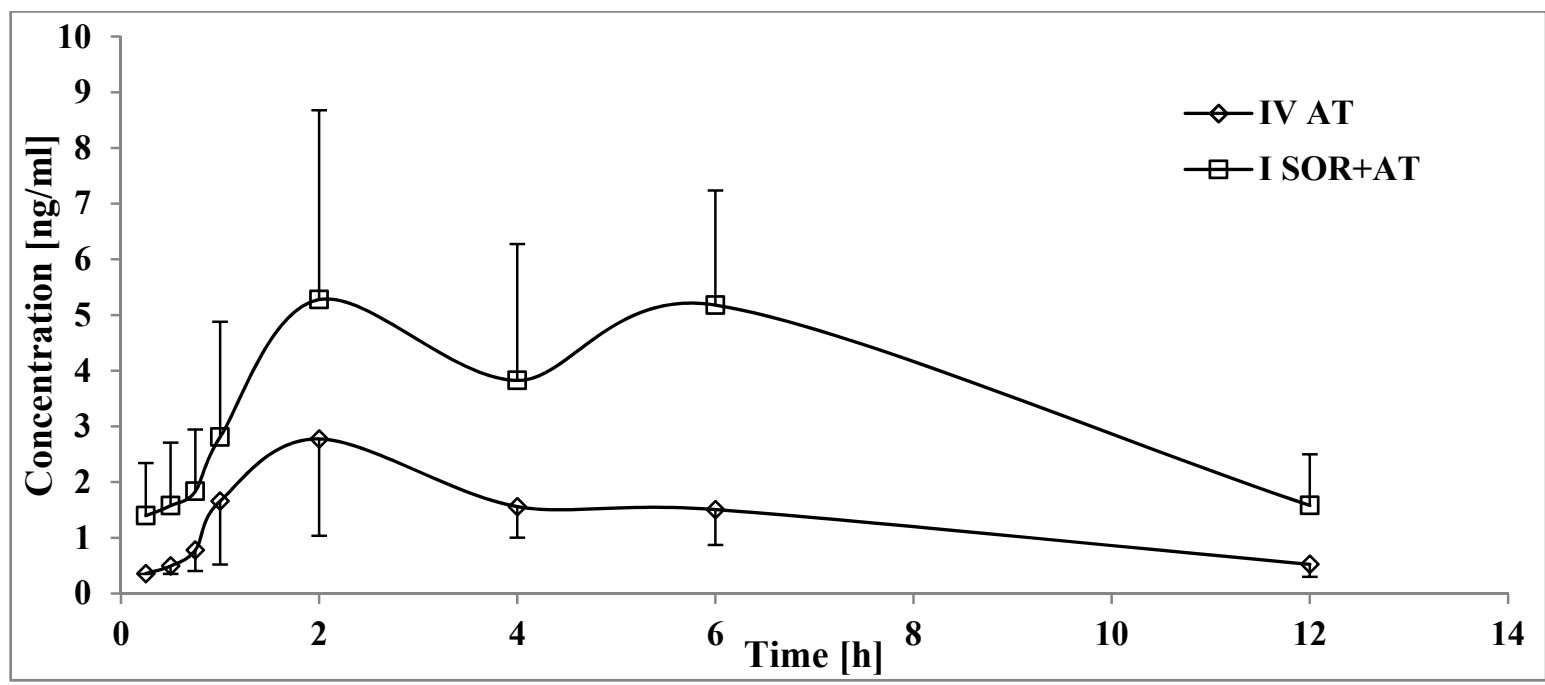

Figure 5. The 4-OH AT plasma concentration-time profiles in rats receiving sorafenib $\left(\mathrm{IV}_{\mathrm{AT}}\right)$ and sorafenib+atorvastatin ( $\left.\mathrm{I}_{\mathrm{SOR}+\mathrm{AT}}\right)$.

\subsection{The Influence of Metformin on the Pharmacokinetics of Sorafenib and SR_NO}

In the presence of metformin (IISOR+MET group,) the sorafenib plasma $\mathrm{AUC}_{0-\mathrm{t}}$ and $\mathrm{AUC}_{0-\infty}$, were 44.0 and $45.1 \%$ lower than those in the III SOR group (Table 2, Figure 1). Metformin decreased the $k_{a}$ by 0.5 -fold. However, the $C_{\max }$ and $t_{\max }$ of sorafenib were comparable. The clearance of sorafenib in the IISOR+MET group was higher by $76.3 \%$ than that in the IIISOR group, but there were no significant differences for $\mathrm{k}_{\mathrm{el}}$ and $\mathrm{t}_{0.5}$. Likewise, the $\mathrm{V}_{\mathrm{d}} / \mathrm{F}$ of sorafenib did not differ significantly between the groups.

All the pharmacokinetic parameters of SR_NO in the II $\mathrm{IIOR}_{\mathrm{SOMT}}$ and III $\mathrm{SOR}_{\text {g }}$ groups were comparable (Table 2, Figure 2).

\subsection{The Influence of Sorafenib on the Pharmacokinetics of Metformin}

Comparing both groups of animals ( $\mathrm{V}_{\mathrm{MET}}$ vs. $\left.\mathrm{II}_{\mathrm{SOR}+\mathrm{MET}}\right)$, statistically significant differences were observed only for $t_{\max }$, which was $71.39 \%$ higher in the IISOR+MET group (Table 4, Figure 6). The values of the other pharmacokinetic parameters were comparable. High values of $C V$ for $k_{a}$ and $k_{e l}$ in the $\mathrm{V}_{\mathrm{MET}}$ and II $\mathrm{SOR+MET}$ groups, respectively, were observed. It may indicate significant inter-individual variability in animals in terms of metformin absorption and elimination.

Table 4. Plasma pharmacokinetic parameters for metformin after the oral administration of a single dose of metformin (100 $\mathrm{mg} / \mathrm{kg}$ b.w.) to the $\mathrm{V}_{\mathrm{MET}}$ group and sorafenib+metformin $(100 \mathrm{mg} / \mathrm{kg}$ b.w. $+100 \mathrm{mg} / \mathrm{kg}$ b.w.) to the IISOR+MET group.

\begin{tabular}{|c|c|c|c|}
\hline $\begin{array}{l}\text { Pharmacokinetic } \\
\text { Parameters }{ }^{1}\end{array}$ & $\begin{array}{l}\mathrm{V}_{\text {MET }} \\
(n=8)\end{array}$ & $\begin{array}{c}\mathrm{II}_{\mathrm{SOR}+\mathrm{MET}} \\
(n=8)\end{array}$ & $\begin{array}{c}p \text {-Value } \\
\text { II }_{\text {SOR+MET }} \text { vs. } \mathrm{V}_{\text {MET }}\end{array}$ \\
\hline $\mathrm{C}_{\max }(\mu \mathrm{g} / \mathrm{mL})$ & $\begin{array}{c}0.50 \pm 0.29 \\
\quad(58.0)\end{array}$ & $\begin{array}{l}0.46 \pm 0.26 \\
\quad(56.5)\end{array}$ & $0.9581^{1}$ \\
\hline $\mathrm{AUC}_{0-\mathrm{t}}(\mu \mathrm{g} \times \mathrm{h} / \mathrm{mL})$ & $\begin{array}{c}3.83 \pm 1.23 \\
\quad(32.1)\end{array}$ & $\begin{array}{c}3.64 \pm 1.15 \\
\quad(31.6)\end{array}$ & $0.5635^{1}$ \\
\hline $\mathrm{AUC}_{0-\infty}(\mu \mathrm{g} \times \mathrm{h} / \mathrm{mL})$ & $\begin{array}{c}7.90 \pm 1.93 \\
(24.4)\end{array}$ & $\begin{array}{c}10.88 \pm 4.50 \\
(41.4)\end{array}$ & $0.1035^{1}$ \\
\hline $\mathrm{t}_{\max }(\mathrm{h})$ & $\begin{array}{c}1.09 \pm 0.57 \\
(52.3)\end{array}$ & $\begin{array}{c}1.88 \pm 0.23 \\
(12.2)\end{array}$ & $0.0069^{2}$ \\
\hline $\mathrm{k}_{\mathrm{a}}\left(\mathrm{h}^{-1}\right)$ & $\begin{array}{c}5.20 \pm 5.22 \\
\quad(100.4)\end{array}$ & $\begin{array}{c}5.06 \pm 4.36 \\
(86.2)\end{array}$ & $0.9536^{2}$ \\
\hline
\end{tabular}


Table 4. Cont.

\begin{tabular}{|c|c|c|c|}
\hline $\begin{array}{l}\text { Pharmacokinetic } \\
\text { Parameters }{ }^{1}\end{array}$ & $\begin{array}{l}\mathrm{V}_{\text {MET }} \\
(n=8)\end{array}$ & $\begin{array}{c}\mathrm{II}_{\mathrm{SOR}+\mathrm{MET}} \\
(n=8)\end{array}$ & $\begin{array}{c}p \text {-Value } \\
\text { II }_{\text {SOR+MET }} \text { vs. } \text { V }_{\text {MET }}\end{array}$ \\
\hline $\mathrm{k}_{\mathrm{el}}\left(\mathrm{h}^{-1}\right)$ & $\begin{array}{c}0.03 \pm 0.01 \\
(33.3)\end{array}$ & $\begin{array}{c}0.03 \pm 0.04 \\
(133.3)\end{array}$ & $0.9039^{2}$ \\
\hline $\mathrm{t}_{1 / 2}(\mathrm{~h})$ & $\begin{array}{c}26.54 \pm 14.52 \\
(54.7)\end{array}$ & $\begin{array}{c}51.51 \pm 36.59 \\
\quad(71.0)\end{array}$ & $0.0944^{2}$ \\
\hline $\mathrm{Cl} / \mathrm{F}(\mathrm{L} / \mathrm{h})$ & $\begin{array}{c}6.31 \pm 1.48 \\
(23.5)\end{array}$ & $\begin{array}{c}5.50 \pm 3.08 \\
(56.0)\end{array}$ & $0.1893^{1}$ \\
\hline $\mathrm{V}_{\mathrm{d}} / \mathrm{F}(\mathrm{L})$ & $\begin{array}{c}227.66 \pm 90.97 \\
(39.9)\end{array}$ & $\begin{array}{c}297.89 \pm 133.23 \\
(44.7)\end{array}$ & $0.2271^{1}$ \\
\hline $\mathrm{MRT}_{0-\mathrm{t}}(\mathrm{h})$ & $\begin{array}{c}9.81 \pm 1.27 \\
(12.9)\end{array}$ & $\begin{array}{c}8.65 \pm 2.22 \\
(25.7)\end{array}$ & $0.2202^{2}$ \\
\hline
\end{tabular}

$\mathrm{C}_{\max }$, maximum observed plasma concentration; $\mathrm{AUC}_{0-\mathrm{t}}$, area under the plasma concentration-time curve from zero to the time of last measurable concentration; $\mathrm{AUC}_{0-\infty}$, area under the plasma concentration-time curve from zero to infinity; $t_{\max }$, time to the first occurrence of $C_{\max } ; \mathrm{k}_{\mathrm{a}}$, absorption rate constant; $\mathrm{k}_{\mathrm{el}}$, elimination rate constant; $t_{1 / 2}$, half-life in the elimination phase; $C l / F$, apparent plasma drug clearance; $\mathrm{V}_{\mathrm{d}} / \mathrm{F}$, apparent volume of distribution; b.w., body weight. Arithmetic means \pm standard deviations (SD) are shown with coefficients of variation (CV) $(\%)$ in brackets; ${ }^{1}$ t-test; ${ }^{2}$ Mann-Whitney test.

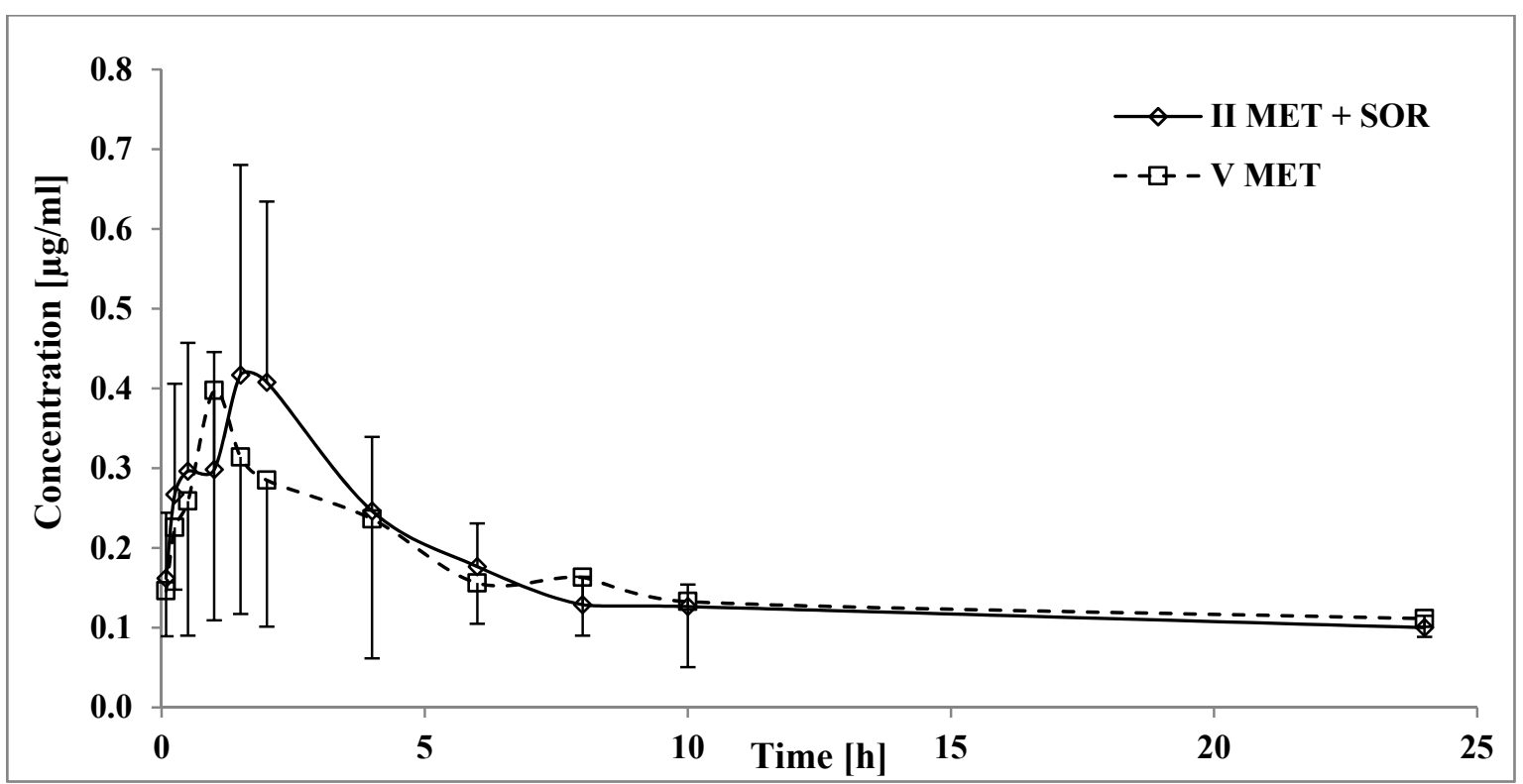

Figure 6. The metformin plasma concentration-time profiles in rats receiving metformin $\left(\mathrm{V}_{\mathrm{MET}}\right)$ and sorafenib+metformin $\left(\mathrm{II}_{\mathrm{SOR}+\mathrm{MET}}\right)$.

\section{Discussion}

To properly evaluated our findings, it is important to note the limitations of the conducted studies. First of all, no animal model used in the experiment experienced HCC or T2DM, and as we know from our previous in vivo study with streptozotocin-induced diabetic Wistar rats receiving only sorafenib, T2DM has its impact upon exposure to sorafenib [31]. Additionally, the pharmacokinetic profile of sorafenib, metformin, and atorvastatin may differ between Wistar rats and humans, and the concentrations of sorafenib glucuronide were not measured.

On the other hand, since we used non-diabetic rats, this condition did not enhance the exposure to sorafenib and SR_NO [31], and therefore, we were able to examine potential pharmacokinetic DDIs in this animal model.

The doses of metformin $(100 \mathrm{mg} / \mathrm{kg})$ and atorvastatin $(20 \mathrm{mg} / \mathrm{kg})$ used in our study were selected based on available literature $[27,28,32]$ and did not cause any adverse effects in healthy rats. A dose of atorvastatin of $20 \mathrm{mg} / \mathrm{kg}$ may cause liver injury in diabetic rats [27] but is safe for healthy rats [32]. 
Drug-drug interactions are clinically relevant in humans when changes in the AUC, $C_{\max }$, or clearance are greater than $25 \%$, or there is a statistically significant influence on pharmacodynamics endpoints. For example, for metformin, glycosylated hemoglobin A1c $(\mathrm{HbA1c})$ levels or oral glucose tolerance tests (OGTTs) may be relevant [16,33].

\subsection{The Influence of Atorvastatin on the Pharmacokinetics of Sorafenib and SR_NO}

We found that the co-administration of sorafenib and atorvastatin could lead to a higher risk of adverse reactions to sorafenib, such as hand-foot syndrome, alopecia, gastrointestinal disorders, a hypertensive crisis, or cardiotoxicity [34]. The almost doubling of exposure to sorafenib $(p<0.0001$ for $\mathrm{AUC}_{0-\mathrm{t}}$, and $p=0.0002$ for $\left.\mathrm{AUC}_{0-\infty}\right)$, along with the enhanced $\mathrm{C}_{\max }(+134.6 \%, p<0.0001)$ and $\mathrm{k}_{\mathrm{el}}$ $(+42.9 \%, p=0.0637)$, most closely corresponds to Kalliokoski A. et al.'s results [35]. They concluded, based on a randomized crossover study with healthy volunteers $(n=24)$, that increased mean values of $\mathrm{C}_{\max }$ and AUC for repaglinide (among those who received repaglinide and atorvastatin, $0.25+40 \mathrm{mg}$ ) were most likely the effect of OATP1B1-mediated hepatic uptake inhibition by atorvastatin [34]. Since sorafenib is highly protein-bound [33], there is the potential for it to be released from protein binding by atorvastatin, which would improve the unbound fraction concentration of the chemotherapeutic agent as well. Additionally, an in vitro study on a murine monocytic leukemia cell line overexpressing P-gp showed that the co-use of atorvastatin may result in the increased absorption of P-gp substrates (digoxin and verapamil) [36].

Additional sorafenib N-oxide exposure (Table 2) is probably a consequence of increased exposure to sorafenib. Considering the fact that both sorafenib and SR_NO exhibit inhibitory effects on CYP3A4 [37], and since atorvastatin itself is its substrate, the induction of CYP3A4 is highly unlikely. Since SR_NO exhibits pharmacological activity, the risk of toxicity is further enhanced.

\subsection{The Influence of Sorafenib on the Pharmacokinetics of Atorvastatin, 2-OH AT, and 4-OH AT}

Sorafenib+atorvastatin treatment may also lead to excessive side effects from atorvastatin, such as hyperglycemia, hepatitis, or musculoskeletal and connective tissue disorders [37], due to an almost doubling of the exposure to atorvastatin (Table 4). Since bioavailability $(\mathrm{F})$ depends on the $\mathrm{AUC}_{0-\infty}$ for extravascular administration and is directly proportional, a significant $(p<0.005)$ decrease in CL/F and $\mathrm{V}_{\mathrm{d}} / \mathrm{F}$ is consistent with the reported data. Even though $\mathrm{t}_{\max }$ was prolonged by 2.2-fold $(p=0.0419)$, there were no significant differences for the absorption $\left(C_{\max }, k_{a}\right)$ or elimination $\left(k_{e l}\right.$ or $\left.t_{1 / 2}\right)$ of atorvastatin. The lack of reduction of exposure to 2-OH AT and 4-OH AT among the $\mathrm{I}_{\mathrm{SOR}+\mathrm{AT}}$ group (Figures 4 and 5) suggests that the CYP3A4-mediated metabolism of atorvastatin was not suppressed by sorafenib. In the light of those findings, interaction occurs most likely during atorvastatin distribution at the protein transporter level. The overlap between sorafenib and atorvastatin transporter-related activity suggests that the induction of efflux transporters (P-glycoprotein) and/or inhibition of atorvastatin hepatic uptake transporters (Oatp1b1/3) by sorafenib could play a significant role in this DDI $[5,38]$.

Furthermore, as a consequence of the highly enhanced exposure to atorvastatin, the concentration of its metabolites (2-OH AT and 4-OH AT) should increase as well. However, decreases in the 2-OH $\mathrm{AT} /$ atorvastatin ratios for the $\mathrm{AUC}_{0-\mathrm{t}}(-19.4 \%)$ and $\mathrm{AUC}_{0-\infty}(-26.0 \%, p=0.0312)$ (Table 3 ) may suggest a smaller increase upon exposure to 2-OH AT than expected. However, the differences in the $\mathrm{AUC}_{0-\infty}$ for 2-OH AT and the $\mathrm{AUC}_{0-\mathrm{t}}$ for 2-OH AT/atorvastatin ratio were statistically insignificant, and the $\mathrm{C}_{\max }$ for 2-OH AT remains comparable. At the same time, the $\mathrm{I}_{\mathrm{SOR}+\mathrm{AT}}$ group was heavily exposed to 4-OH AT ( $p=0.0002$ for $\mathrm{AUC}_{0-\mathrm{t}}, p=0.0001$ for $\mathrm{AUC}_{0-\infty}$, and $p=0.0019$ for $\mathrm{C}_{\max }$ ), which resulted in $2.5-, 1.6-$, and 1.7-fold increases in the $\mathrm{C}_{\max }(p=0.0084), \mathrm{AUC}_{0-\mathrm{t}}(p=0.0239)$, and $\mathrm{AUC}_{0-\infty}(p=0.0239)$ for the 4-OH AT/atorvastatin ratio, respectively, as well. The reported data suggest that the presence of sorafenib altered the proportions of 2-OH AT and 4-OH AT, in favor of 4-OH AT. 


\subsection{The Influence of Metformin on the Pharmacokinetics of Sorafenib and SR_NO}

The co-administration of metformin with sorafenib significantly reduced and nearly halved rats' exposure to the chemotherapeutic agent (Figure 1$)$, and the increased CL/F value $(p<0.005)$ is consistent with the reported data (Table 2). Furthermore, when a 0.5 -fold decrease in the absorption rate constant is compared to the inconsistent changes in elimination-related parameters, interaction at the absorption level seems to occur. Since the $C_{\max }$ and $t_{\max }$ values were comparable among the study and control groups, the possibility of interference within the protein-bound sorafenib fraction may be ruled out. Additionally, accelerated intestinal passage is one of the most common adverse reactions observed in patients during metformin treatment [39], and a clinically important interaction between a high-fat diet and sorafenib (resulting in a 30\% decrease in sorafenib absorption) is known as well [34]. Although the defecation rate noted during the experiment was not unusual, it might interrupt the intestinal absorption and enterohepatic cycle, and eventually decrease sorafenib exposure.

Furthermore, despite the decreased exposure to sorafenib, all the pharmacokinetic parameters of SR_NO were still comparable in both the study and control groups (Table 2), which resulted in a 2.3-fold increased value of the $\mathrm{AUC}_{0-\mathrm{t}}$ for SR_NO/sorafenib ratios in the IISOR+MET group vs. the IIISOR group $(p=0.0002)$. Since SR_G plays a crucial role in the enterohepatic circulation of sorafenib [5], it is more likely that the increased SR_NO/sorafenib exposure ratios are a result of rapid intestinal transit, which shortens the time for SR_G transformation to sorafenib and sorafenib re-absorption, than a result of CYP3A4-mediated DDIs. However, sorafenib itself has shown CYP3A4-inhibitory properties in an in vitro study [37,40], and therefore, metformin could promote the CTP3A4-mediated pathway by alleviating the obstacles (by sorafenib concentration reduction). However, this metabolization hypothesis seems to be less established, especially considering that the direct impact of metformin on CYP3A4 activity remains largely unknown [41]. Although the pharmacological activity of sorafenib $\mathrm{N}$-oxide and sorafenib are comparable [34], a halved exposure to sorafenib carries the risk of reduced, unsatisfactory responses to oncological treatment.

\subsection{The Influence of Sorafenib on the Pharmacokinetics of Metformin}

It has been shown that there are several drugs, inhibitors, that can cause an increase in the $\mathrm{C}_{\max }$ and AUC of metformin, e.g., cimetidine (inhibits MATE1 in the kidneys) [42], cephalexin [43], topiramate [44], trimethoprim [45] (reduces the clearance of metformin), vandetanib (inhibits OCT2) [46], and pyrimethamine (competitively inhibits both MATE1 and MATE2) [47].

However, in our study, sorafenib did not significantly affect the total exposure to metformin in rats (Figure 6), and the $C_{\max }$ values of metformin in the $V_{M E T}$ and the IISOR+MET groups were comparable (Table 4). After the combined use of these two drugs, only an increase in the $t_{\max }$ of metformin (by $71.39 \%, p=0.0069$ ) was observed. Those data suggest that DDIs during the absorption process may occur. Metformin is known for its saturable absorption and prolongs $t_{\max }$ due to its co-administration with food $[14,39]$. Since both PMAT and OCT1 transporters participate in the intestinal uptake of metformin, and sorafenib is still considered as an OCT1 substrate, these proteins might be a direct cause of metformin-sorafenib DDI [5,14].

Studies have reported that metformin partitions into erythrocytes, which are most likely its second compartment [14]. However, since the $C_{\max }$ values remain comparable between the study and control groups, interference within this fraction is insignificant.

\section{Conclusions}

Statins are commonly used by elderly patients that usually also struggle with other conditions, including kidney and liver disorders (these organs are important for proper xenobiotic elimination). Since that population is at a higher risk of presenting with cancer, further pharmacokinetic studies of sorafenib-atorvastatin interaction in patients are needed. Moreover, plasma sorafenib and SR_NO monitoring during sorafenib-atorvastatin therapy might be beneficial for preventing sorafenib overdose. 
Since 2-OH AT and 4-OH AT are together responsible for approximately $70 \%$ of the therapeutic activity of atorvastatin [32], and its profiles were strongly affected by the presence of sorafenib, it is also important to evaluate the influence of sorafenib-atorvastatin therapy on its pharmacokinetics in future clinical studies as well.

It can be assumed that in clinical practice, the combined use of sorafenib and metformin in HCC therapy will probably not result in an increase in the plasma levels of metformin and, thus, the risk of its side effects. It should also be noted that genetic variation in OCTs, MATEs, and PMAT transporter genes may bias the metformin plasma and intracellular levels and, hence, the patient's response to metformin [16]. At the same time, there is a growing need to clarify the potential impact of metformin on sorafenib's and sorafenib N-oxide's pharmacokinetics, both in patients and possibly with a suitable time interval between the administration of those two drugs. However, it should be remembered that altered drug pharmacokinetics are not always translatable into significant pharmacodynamic changes. Further clinical studies should investigate pharmacokinetic relationships between drugs, in parallel with the pharmacological effect of combined therapies, as they may occur in patients as well.

Author Contributions: Conceptualization, A.K. and E.S.; methodology, A.K., J.S.-R., and D.S.-F..; software, A.C., M.K.-Ł., and A.W.; validation, A.K., A.C., and M.K-Ł.; formal analysis, A.K., D.S.-F., and E.S.; investigation, A.K., D.S.-F., N.K., P.K., and M.B.; resources, A.K. and D.S.-F.; data curation, A.K.; writing-original draft preparation, A.K., J.S.-R., and N.K.; writing—review and editing, A.K., A.C., and N.K.; visualization, A.K., A.C., and D.S.-F.; supervision, E.G. and F.G.; project administration, E.S.; funding acquisition, N.K. and P.K. All authors have read and agreed to the published version of the manuscript.

Funding: This research was funded by Poznan University of Medical Sciences, grant numbers 502-01-33114230-3553 (to N.K.) and 502-01-33114230-3557 (to P.K.). The APC was funded by POZNAN UNIVERSITY OF MEDICAL SCIENCES.

Conflicts of Interest: The authors declare no conflict of interest. The funders had no role in the design of the study; in the collection, analyses, or interpretation of data; in the writing of the manuscript; or in the decision to publish the results.

\section{References}

1. Bertot, L.C.; Adams, L.A. Trends in hepatocellular carcinoma due to non-alcoholic fatty liver disease. Expert Rev. Gastroenterol. Hepatol. 2019, 13, 179-187. [CrossRef] [PubMed]

2. Mao, M.; Wang, X.; Sheng, H.; Yijun, L.; Zhang, L.; Dai, S.; Chi, P.D. A novel score based on serum apolipoprotein A-1 and C-reactive protein is a prognostic biomarker in hepatocellular carcinoma patients. BMC Cancer 2018, 18, 1178. [CrossRef] [PubMed]

3. Di Costanzo, G.G.; Tortora, R.; Morisco, F.; Addario, L.; Guarino, M.; Cordone, G.; Falco, L.; Caporaso, N. Impact of diabetes on outcomes of sorafenib therapy for hepatocellular carcinoma. Target Oncol. 2017, 12, 61-67. [CrossRef] [PubMed]

4. Hassan, M.M.; Curley, S.A.; Li, D.; Kaseb, A.; Davila, M.; Abdalla, E.K.; Javle, M.; Moghazy, D.M.; Lozano, R.D.; Abbruzzese, J.L.; et al. Association of diabetes duration and diabetes treatment with the risk of hepatocellular carcinoma. Cancer 2010, 116, 1938-1946. [CrossRef]

5. Gong, L.; Giacomini, M.M.; Giacomini, C.; Maitland, M.L.; Altman, R.B.; Klein, T.E. PharmGKB summary: Sorafenib pathways. Pharm. Genom. 2017, 27, 240-246. [CrossRef]

6. Chen, M.; Neul, C.; Schaeffeler, E.; Frisch, F.; Winter, S.; Schwab, M.; Koepsell, H.; Hu, S.; Laufer, S.; Baker, S.D.; et al. Sorafenib activity and disposition in liver cancer does not depend on organic cation transporter 1. Clin. Pharm. Ther. 2020, 107, 227-237. [CrossRef]

7. Vasilyeva, A.; Durmus, S.; Li, L.; Wagenaar, E.; Hu, S.; Gibson, A.A.; Panetta, J.C.; Mani, S.; Sparreboom, A.; Baker, S.D.; et al. Hepatocellular shuttling and recirculation of sorafenib-glucuronide is dependent on Abcc2, Abcc3, and Oatp1a/1b. Cancer Res. 2015, 75, 2729-2736. [CrossRef]

8. International Transporter Consortium; Giacomini, K.M.; Huang, S.M.; Tweedie, D.J.; Benet, L.Z.; Brouwer, K.L.R.; Chu, X.; Dahlin, A.; Evers, R.; Fischer, V.; et al. Membrane transporters in drug development. Nat. Rev. Drug. Discov. 2010, 9, 215-236. [CrossRef] 
9. Wang, Z.; Yang, H.; Xu, J.; Zhao, K.; Chen, Y.; Liang, L.; Li, P.; Chen, N.; Geng, D.; Zhang, X.; et al. Prediction of atorvastatin pharmacokinetics in high-fat diet and low-dose streptozotocin-induced diabetic rats using a semiphysiologically based pharmacokinetic model involving both enzymes and transporters. Drug Metab. Dispos. 2019, 47, 1066-1079. [CrossRef]

10. Bil, J.; Zapala, L.; Nowis, D.; Jakobisiak, M.; Golab, J. Statins potentiate cytostatic/cytotoxic activity of sorafenib but not sunitinib against tumor cell lines in vitro. Cancer Lett. 2010, 288, 57-67. [CrossRef]

11. Mohammadalipour, A.; Hashemnia, M.; Goudarzi, F.; Ravan, A.P. Increasing the effectiveness of tyrosine kinase inhibitor (TKI) in combination with a statin in reducing liver fibrosis. Clin. Exp. Pharm. Physiol. 2019, 46, 1183-1193. [CrossRef]

12. Hwang, K.E.; Kwon, S.J.; Kim, Y.S.; Park, D.S.; Kim, B.R.; Yoon, K.H.; Jeong, E.K.; Kim, H.R. Effect of simvastatin on the resistance to EGFR tyrosine kinase inhibitors in a non-small cell lung cancer with the T790M mutation of EGFR. Exp. Cell Res. 2014, 323, 288-296. [CrossRef]

13. Hung, M.S.; Chen, I.C.; Lee, C.P.; Huang, R.J.; Chen, P.C.; Tsai, Y.H.; Yang, Y.H. Statin improves survival in patients with EGFR-TKI lung cancer: A nationwide population-based study. PLoS ONE 2017, 12, e0171137. [CrossRef]

14. Scheen, A.J. Clinical Pharmacokinetics of Metformin. Clin. Pharm. 1996, 30, 359-371. [CrossRef] [PubMed]

15. Gong, L.; Goswami, S.; Giacomini, K.M.; Altman, R.B.; Klein, T.E. Metformin pathways: Pharmacokinetics and pharmacodynamics. Pharm. Genom. 2012, 22, 820-827. [CrossRef] [PubMed]

16. Stage, T.B.; Brøsen, K.; Christensen, M.M. A comprehensive review of drug-drug interactions with metformin. Clin. Pharm. 2015, 54, 811-824. [CrossRef] [PubMed]

17. Chung, Y.G.; Tak, E.; Hwang, S.; Lee, J.Y.; Kim, J.Y.; Kim, Y.Y.; Song, G.W.; Lee, K.J.; Kim, N. Synergistic effect of metformin on sorafenib in in vitro study using hepatocellular carcinoma cell lines. Ann. Hepatobiliary Pancreat Surg. 2018, 22, 179-184. [CrossRef]

18. Orsi, G.; Casadei-Gardini, A. Sorafenib and metformin: To be, or not to be, that is the question. Hepatobiliary Surg Nutr. 2019, 8, 411-413. [CrossRef]

19. Wang, Q.Q.; Guo, X.C.; Li, L.; Gao, Z.H.; Ji, M. Treatment with metformin and sorafenib alleviates endometrial hyperplasia in polycystic ovary syndrome by promoting apoptosis via synergically regulating autophagy. J. Cell Physiol. 2020, 235, 1339-1348. [CrossRef]

20. Ling, S.; Song, L.; Fan, N.; Feng, T.; Liu, L.; Yang, X.; Wang, M.; Li, Y.; Tian, Y.; Zhao, F. Combination of metformin and sorafenib suppresses proliferation and induces autophagy of hepatocellular carcinoma via targeting the mTOR pathway. Int. J. Oncol. 2017, 50, 297-309. [CrossRef]

21. Chen, G.; Nicula, D.; Renko, K.; Derwahl, M. Synergistic anti-proliferative effect of metformin and sorafenib on growth of anaplastic thyroid cancer cells and their stem cells. Oncol. Rep. 2015, 33, 1994-2000. [CrossRef] [PubMed]

22. Schulte, L.; Scheiner, B.; Voigtländer, T.; Koch, S.; Schweitzer, N.; Marhenke, S.; Ivanyi, R.; Manns, M.P.; Rodt, T.; Hinrichs, J.B. Treatment with metformin is associated with a prolonged survival in patients with hepatocellular carcinoma. Liver Int. 2019, 39, 714-726. [CrossRef] [PubMed]

23. Gardini, A.C.; Faloppi, L.; De Matteis, S.; Foschi, F.G.; Silvestris, N.; Tovoli, F.; Palmieri, V.; Marisi, G.; Brunetti, O.; Vespasiani-Gentilucci, U.; et al. Metformin and insulin impact on clinical outcome in patients with advanced hepatocellular carcinoma receiving sorafenib: Validation study and biological rationale. Eur. J. Cancer 2017, 86, 106-114. [CrossRef] [PubMed]

24. Gardini, A.C.; Marisi, G.; Scarpi, E.; Scartozzi, M.; Faloppi, L.; Silvestris, N.; Masi, C.; Vivaldi, C.; Brunetti, O.; Tamberi, S.; et al. Effects of metformin on clinical outcome in diabetic patients with advanced HCC receiving sorafenib. Expert Opin. Pharm. 2015, 16, 2719-2725. [CrossRef]

25. Minematsu, T.; Giacomini, K.M. Interactions of tyrosine kinase inhibitors with organic cation transporters and multidrug and toxic compound extrusion proteins. Mol. Cancer Ther. 2011, 10, 531-539. [CrossRef] [PubMed]

26. Wang, X.; Zhang, X.; Liu, F.; Wang, M.; Qin, S. The effects of triptolide on the pharmacokinetics of sorafenib in rats and its potential mechanism. Pharm. Biol. 2017, 55, 1863-1867. [CrossRef]

27. Shu, N.; Hu, M.; Ling, Z.; Liu, P.; Wang, F.; Xu, P.; Zhong, Z.; Sun, B.; Zhang, M.; Li, F.; et al. The enhanced atorvastatin hepatotoxicity in diabetic rats was partly attributed to the upregulated hepatic Cyp3a and SLCO1B1. Sci. Rep. 2016, 6, 33072. [CrossRef] [PubMed] 
28. Shi, R.; Xu, Z.; Xu, X.; Jin, J.; Zhao, Y.; Wang, T.; Li, Y.; Ma, Y. Organic cation transporter and multidrug and toxin extrusion 1 co-mediated interaction between metformin and berberine. Eur. J. Pharm. Sci. 2019, 127, 282-290. [CrossRef]

29. Afify, S.; Rapp, U.R.; Högger, P. Validation of a liquid chromatography assay for the quantification of the Raf kinase inhibitor BAY 43-9006 in small volumes of mouse serum. J. Chromatogr. B Analyt. Technol. Biomed. Life Sci. 2004, 809, 99-103. [CrossRef]

30. Gabr, R.Q.; Padwal, R.S.; Brocks, D.R. Determination of metformin in human plasma and urine by high-performance liquid chromatography using small sample volume and conventional octadecyl silane column. J. Pharm. Pharm. Sci. 2010, 13, 486-494. [CrossRef]

31. Karbownik, A.; Stachowiak, A.; Urjasz, H.; Sobańska, K.; Szczecińska, A.; Grabowski, T.; Stanisławiak-Rudowicz, J.; Wolc, A.; Grześkowiak, E.; Szałek, E. The oxidation and hypoglycaemic effect of sorafenib in streptozotocin-induced diabetic rats. Pharm. Rep. 2020, 72, 254-259. [CrossRef] [PubMed]

32. Summary of Product Characteristics for Atorvastatin $10 \mathrm{mg}$ film coated tablets. Datapharm Ltd., Electronic Medicines Compendium. Available online: https://www.medicines.org.uk/emc/product/4109/smpc (accessed on 10 February 2020).

33. Drug interaction studies-study design, data analysis, implications for dosing, and labeling recommendations. U.S. Food and Drug Administration. Available online: http://www.fda.gov/downloads/drugs/ guidancecomplianceregulatoryinformation/guidances/ucm292362.pdf (accessed on 29 February 2020).

34. Summary of Product Characteristic for Nexavar $200 \mathrm{mg}$, European Medicines Agency. Available online: https://www.ema.europa.eu/en/documents/product-information/nexavar-epar-product-information_ en.pdf (accessed on 10 February 2020).

35. Kalliokoski, A.; Backman, J.; Kurkinen, K.J.; Neuvonen, P.J.; Niemi, M. Effects of gemfibrozil and atorvastatin on the pharmacokinetics of repaglinide in relation to SLCO1B1 polymorphism. Clin. Pharmacol. Ther. 2008, 84, 488-496. [CrossRef] [PubMed]

36. Bogman, K.; Peyer, A.K.; Török, M.; Küsters, E.; Drewe, J. HMG-CoA reductase inhibitors and P-glycoprotein modulation. Br. J. Pharmacol. 2001, 132, 1183-1192. [CrossRef] [PubMed]

37. Ghassabian, S.; Gillani, T.B.; Rawling, T.; Crettol, S.; Nair, P.C.; Murray, M. Sorafenib N-Oxide is an inhibitor of human hepatic CYP3A4. AAPS J. 2019, 21, 15. [CrossRef]

38. Holtzman, C.W.; Wiggins, B.S.; Spinler, S.A. Role of P-glycoprotein in statin drug interactions. Pharmacotherapy 2016, 26, 1601-1607. [CrossRef]

39. Summary of Product Characteristics for Glucophage $500 \mathrm{mg}$ film coated tablets. Datapharm Ltd., Electronic Medicines Compendium. Available online: https://www.medicines.org.uk/emc/product/987/smpc (accessed on 10 February 2020).

40. Sugiyama, M.; Fujita, K.; Murayama, N.; Akiyama, Y.; Yamazaki, H.; Sasaki, Y. Sorafenib and sunitinib, two anticancer drugs, inhibit CYP3A4-mediated and activate CY3A5-mediated midazolam 1'-hydroxylation. Drug. Metab. Dispos. 2011, 39,757-762. [CrossRef]

41. Krausova, L.; Stejskalova, L.; Wang, H.; Vrzal, R.; Dvorak, Z.; Mani, S.; Pavek, P. Metformin suppresses pregnane $X$ receptor (PXR)-regulated transactivation of CYP3A4 gene. Biochem. Pharmacol. 2011, 82, 1771-1780. [CrossRef]

42. Tsuda, M.; Terada, T.; Ueba, M.; Sato, T.; Masuda, S.; Katsura, T.; Inui, K.I. Involvement of human multidrug and toxin extrusion 1 in the drug interaction between cimetidine and metformin in renal epithelial cells. J. Pharmacol. Exp. Ther. 2009, 329, 185-191. [CrossRef] [PubMed]

43. Jayasagar, G.; Krishna Kumar, M.; Chandrasekhar, K.; Madhusudan Rao, C.; Madhusudan Rao, Y. Effect of cephalexin on the pharmacokinetics of metformin in healthy human volunteers. Drug. Metabol. Drug. Interact. 2002, 19, 41-48. [CrossRef]

44. Manitpisitkul, P.; Curtin, C.R.; Shalayda, K.; Wang, S.S.; Ford, L.; Heald, D. Pharmacokinetic interactions between topiramate and pioglitazone and metformin. Epilepsy Res. 2014, 108, 1519-1532. [CrossRef]

45. Grün, B.; Kiessling, M.K.; Burhenne, J.; Riedel, K.D.; Weiss, J.; Rauch, G.; Haefeli, W.E.; Czock, D. Trimethoprim-metformin interaction and its genetic modulation by OCT2 and MATE1 transporters. Br. J. Clin. Pharm. 2013, 76, 787-796. [CrossRef] [PubMed] 
46. Johansson, S.; Read, J.; Oliver, S.; Steinberg, M.; Li, Y.; Lisbon, E.; Mathews, D.; Leese, P.T.; Martin, P. Pharmacokinetic evaluations of the co-administrations of vandetanib and metformin, digoxin, midazolam, omeprazole or ranitidine. Clin. Pharm. 2014, 53, 837-847. [CrossRef] [PubMed]

47. Kusuhara, H.; Ito, S.; Kumagai, Y.; Jiang, M.; Shiroshita, T.; Moriyama, Y.; Inoue, K.; Yuasa, H.; Sugiyama, Y. Effects of a MATE protein inhibitor, pyrimethamine, on the renal elimination of metformin at oral microdose and at therapeutic dose in healthy subjects. Clin. Pharm. Ther. 2011, 89, 837-844. [CrossRef] [PubMed] 